\title{
Havacılık Sektöründe Zaman Baskısının Teknostrese Etkisi: Uçak Bakım Teknisyenleri Üzerine Bir Araştırma

\author{
(The Effect of Time Pressure on Technostress in Aviation Industry: Research on Aircraft \\ Maintenance Technicians)
}

\author{
Ramazan ÇOBAN iD a Tayfun AYDOĞDU iD $b$ \\ a Hava Kuvvetleri Komutanlığı, 7'nci Ana Jet Üs Komutanlığı, Malatya, Türkiye. ramazancoban26@hotmail.com \\ b Kara Kuvvetleri Komutanlığı, 3'üncü Kara Havacılık Alay Komutanlığı, İzmir, Türkiye. tayfunaydogdu19@gmail.com
}

\begin{tabular}{|c|c|}
\hline MAKALE BİLGİSİ & ÖZET \\
\hline $\begin{array}{l}\text { Anahtar Kelimeler: } \\
\text { Zaman Baskısı Teknostres }\end{array}$ & $\begin{array}{l}\text { Amaç - Bu araştırmanın amacı, havacılık sektöründe zaman baskısının teknostrese etkisini ve } \\
\text { demografik özelliklere göre uçak bakım teknisyenlerinin zaman baskısı ve teknostres algısının } \\
\text { farklılık gösterip göstermediğini incelemektir. }\end{array}$ \\
\hline $\begin{array}{l}\text { Havacılik } \\
\text { Uçak Bakım } \\
\text { İnsan Faktörü }\end{array}$ & $\begin{array}{l}\text { Yöntem - Araştırmanın örneklemini, Malatya ilinde kamu sektöründe çalışan } 177 \text { uçak ve helikopter } \\
\text { bakım teknisyeni oluşturmaktadır. Çalışmada veri toplamak amacıyla anket yöntemi kullanılmıştır. } \\
\text { Anketten elde edilen veriler, SPSS } 21 \text { ve AMOS } 24 \text { paket programlarında ölçek geçerlilik ve } \\
\text { güvenilirlik, doğrulayıcı faktör analizi, korelasyon, basit doğrusal regresyon, T-testi ve ANOVA } \\
\text { analizlerine tabi tutulmuştur. }\end{array}$ \\
\hline $\begin{array}{l}2020 \\
\text { Revizyon Tarihi } 16 \text { Haziran } \\
2020 \\
\text { Kabul Tarihi } 30 \text { Temmuz } 2020\end{array}$ & $\begin{array}{l}\text { Bulgular - Araştırma sonucuna göre, havacilık sektöründe zaman baskısının teknostresi pozitif } \\
\text { olarak etkilediği; yaş grubu ve eğitim seviyesine göre bakım teknisyenlerinin zaman baskısı } \\
\text { algısının ve çalışma süresi ile eğitim seviyesine göre teknostres algisının farklılık gösterdiği } \\
\text { görülmüştür. Medeni durum ve görev ünvanına göre, bakım teknisyenlerinin zaman baskısı ve } \\
\text { teknostres algısında anlamlı bir farklılık olmadığı görülmüştür. }\end{array}$ \\
\hline $\begin{array}{l}\text { Makale Kategorisi: } \\
\text { Araştırma Makalesi }\end{array}$ & $\begin{array}{l}\text { Tartışma - Havacılık sektöründe yapılan bu çalışmada, zaman baskısı ve teknostresin pozitif yönde } \\
\text { ilişkili olduğu ve zaman baskısının bakım teknisyenlerinin teknostres algısındaki değişimin bir } \\
\text { belirleyicisi olduğu tespit edilmiştir. Demografik özelliklere göre teknisyenlerin zaman baskısı ve } \\
\text { teknostres algısı farklılık göstermektedir. Zaman baskısı ve teknostresin uçak bakım sektöründe } \\
\text { insan faktöründen kaynaklanan hatalara neden olabileceğini söylemek mümkündür. Çalışmanın } \\
\text { havacılık, uçak bakım ve uçuş emniyeti ile ilgili literatüre katkı sağlayacağı düşünülmektedir. }\end{array}$ \\
\hline
\end{tabular}

\begin{tabular}{|c|c|}
\hline ARTICLE INFO & ABSTRACT \\
\hline $\begin{array}{l}\text { Keywords: } \\
\text { Time Pressure Technostress }\end{array}$ & $\begin{array}{l}\text { Purpose - The purpose of this study is to examine the effect of time pressure on technostress in } \\
\text { aviation industry and whether the time pressure and technostress perception of aircraft maintenance } \\
\text { technicians differ according to demographic characteristics. }\end{array}$ \\
\hline $\begin{array}{l}\text { Aviation } \\
\text { Aircraft Maintenance } \\
\text { Human Factor }\end{array}$ & $\begin{array}{l}\text { Design/methodology/approach - The sampling of the study consists of } 177 \text { aircraft and helicopter } \\
\text { maintenance technicians working in the public sector in Malatya province. Questionnaire method } \\
\text { was used to collect data in the study. The data obtained from the questionnaire were subjected to } \\
\text { scale validity and reliability, confirmatory factor analysis, correlation, simple linear regression, T- } \\
\text { test and ANOVA analysis in SPSS } 21 \text { and AMOS } 24 \text { package programs. }\end{array}$ \\
\hline $\begin{array}{l}\text { Received } 17 \text { May } 2020 \\
\text { Revised } 16 \text { June } 2020 \\
\text { Accepted } 30 \text { July } 2020\end{array}$ & $\begin{array}{l}\text { Findings - According to the research results, it was seen that time pressure positively affects the } \\
\text { technostress in the aviation industry. It was observed that the perception of time pressure of } \\
\text { maintenance technicians according to the age group and education level, and the perception of } \\
\text { technostress according to the working time and education level differ. However, according to the } \\
\text { marital status and job title, it was observed that there is no significant difference in maintenance } \\
\text { technicians' time pressure and technostress perception. }\end{array}$ \\
\hline $\begin{array}{l}\text { Article Classification: } \\
\text { Research Article }\end{array}$ & $\begin{array}{l}\text { Discussion - In this study carried out in the aviation industry, it was determined that time pressure } \\
\text { and technostress are positively related and time pressure is a determinant of the change in the } \\
\text { perception of technostress of maintenance technicians. According to demographic characteristics, } \\
\text { technicians' time pressure and technostress perception differ. It is possible to say that time pressure } \\
\text { and technostress can cause errors caused by the human factor in the aircraft maintenance industry. } \\
\text { The study is thought to make a contribution to the literature related to the aviation, aircraft } \\
\text { maintenance and flight safety. }\end{array}$ \\
\hline
\end{tabular}




\section{Giriş}

Küreselleşme ve teknolojik değişimler nedeniyle hızlı bir tempoya sahip günümüz iş hayatında çalışanların birçok örgütsel davranış ve kararı belirli bir zaman dâhilinde gerçekleşmektedir. İşlerin belirlenen zamanda yapılması, örgütsel hedeflere ulaşmak için işletmeler tarafından istenilen bir durumdur. Bu nedenle örgütsel faaliyetlerin yerine getirilmesinde zaman, verimli kullanılması ve iyi yönetilmesi gereken önemli bir kaynak haline gelmiştir. İyi yönetilemeyen zaman ise, çalışanların performansını baskı altına alan önemli bir örgütsel faktör olarak ortaya çıkmaktadır. Schreuder ve Mioch'e (2011: 65) göre zaman baskısı, bir işi yapmak için gerekli zaman az olduğunda bireyde ortaya çıkan algıdır. Zaman baskısı altındaki bireyler, alternatifler üzerinde düşünmeyi bırakıp daha hızlı performans göstermeye, analitik kararlar yerine sezgisel kararlar almaya ve bilgi işleme sürecinde derinlemesine değil yüzeysel düşünmeye çalışır. Zaman baskısı, bir işi yaparken mevcut sınırlı zamanın sebep olduğu psikolojik duygu durumu ve deneyimidir. Zaman baskısı, çoğunlukla bireylerin karar alma sürecini ve örgütsel performansı negatif olarak etkileyen önemli bir stres kaynağıdır (Saptari vd., 2015: 1).

Rekabetin sürekli ve kaçınılmaz olduğu iş çevresinde rakiplerine üstünlük sağlamak isteyen işletmeler sektörel, ulusal ve küresel pazarda ayakta kalabilmek adına gelişmiş teknolojileri kullanmak zorundadır. Günümüz modern dünyasında öncelikle bilgi ve iletişim sistemleri olmak üzere kullanılan birçok teknolojik araç, hayatımızı son derece kolaylaştırmaktadır. Teknoloji, örgütsel performansın etkin ve verimli olmasında önemli katkılar sağlamakla birlikte, bazı durumlarda çalışanların örgütsel davranışını negatif olarak etkileyen ve çalışanları strese sokan bir örgütsel faktör haline gelmektedir. Brod (1984), bireylerin yeni teknolojiler ile sağlıklı bir şekilde başa çıkamaması sonucu ortaya çıkan teknostresi, modern bir psikosomatik rahatsızlık olarak tanımlamıştır. Örgütsel faaliyetlerin yerine getirilmesinde çoğunlukla bilgi ve iletişim teknolojilerinin kullanılması nedeniyle aşırı iş yüküne, sık sistem güncellemelerine, sürekli yeniden öğrenmeye, teknolojik karmaşıklığa ve teknik sorunlara maruz kalmak çalışanların teknostres yaşamasına sebep olmaktadır (Tarafdar vd., 2011: 304). İş hayatındaki hızla değişen karmaşık teknolojik çevreye uyum sağlama sürecinde öne çıkan örgütsel faktörler ve çalışanların demografik özellikleri algılanan teknostresi etkilemektedir (Türen vd., 2015: 4).

Teknolojik gelişmelere bağlı olarak tüm dünyada hızlı bir şekilde büyüyen havacılık sektörünün, ulaşım sektörü içindeki payı gün geçtikçe artmaktadır. Uluslararası sıkı kurallar çerçevesinde hareket eden havacılık sektöründe faaliyetlerin emniyetli bir şekilde yerine getirilmesinde uçak bakım faaliyetlerinin katkısı büyüktür. Havacilık sektörünün önemli bir bileşeni olan uçak bakım sektörü; insan faktörü hatalarının görüldüğü, zor ve karmaşık faaliyetleri kapsayan bir sektördür. Virovac vd.'ne (2017: 257) göre, havacilık sektörünün genelinde görülen insan faktörü, bir bireyin işini yaparken istem dışı olarak yapılan ve sonucunda bir zararın ortaya çıktığı insan hatalarını tanımlamaktadır. 1990'lı yılların başından itibaren uçak bakım sektöründe insan faktörü kaynaklı hatalar üzerinde yapılan çalışmalar sonucunda, diğer birçok faktörle birlikte zaman baskısı ve stresin uçak bakım teknisyenlerinin hata yapmasına neden olduğu görülmüştür. Sivil havacılık sektöründe hava yolu işletmelerinin ticari kaygıları, askeri havacılıkta ise ani gelişen güvenlik risklerini etkisiz hale getirmek için yapılan harekât uçuşları nedeniyle uçak bakım teknisyenleri çoğunlukla zaman baskısı altında çalışır (Yazgan ve Kavsaoğlu, 2017: 100; Çoban, 2019: 54). Bununla birlikte hem sivil hem de askeri havacılık sektöründe teknoloji kullanımı yüksek seviyededir. Bundan dolayı, merkezinde bakım teknisyenlerinin olduğu uçak bakım faaliyetlerinde teknolojik malzeme, cihaz ve ekipman sıklıkla kullanılmaktadır (Padil vd., 2018: 1). Teknolojinin yoğun olarak kullanıldığı bir iş ortamında bakım teknisyenlerinin teknostres yaşaması muhtemeldir.

$\mathrm{Bu}$ çalışmanın araştırma konusuna karar verme sürecinde dünyada ve ülkemizde gelişmekte olan ve nicel örgütsel davranış araştırmalarının sınırlı olduğu havacılık sektöründe, uçak bakım faaliyetlerinin icra edilmesi sırasında bakım teknisyenlerinin insan faktörü kaynaklı hata yapmasına neden olabilecek örgütsel faktörler üzerinde durulmuştur. $\mathrm{Bu}$ nedenle, zaman baskısı ve teknostresin bakım teknisyenlerinin performansını etkileyebilecek ve birbiriyle ilişkili iki kavram olabileceği; zaman baskısı altında teknisyenlerin daha fazla teknostres hissedebileceği ve teknisyenlerin demografik özelliklerine göre algıladıkları zaman baskısı ve teknostres seviyesinin farklılık gösterebileceği düşünülmüştür. Bununla birlikte havacılık ve uçak bakım sektöründe zaman baskısı ve teknostres kavramlarıyla ilgili araştırmaların (Türen vd., 2015; Alam, 2016; Cheng, 2018; Çoban, 2019) literatürde sınırlı sayıda olduğu görülmüştür. Bu kapsamda bu araştırmanın amacı, havacılık sektöründe zaman baskısının teknostrese etkisini ve demografik özelliklere göre bakım 
teknisyenlerinin zaman baskısı ve teknostres algısının farklılık gösterip göstermediğini ortaya koymaktır. Araştırmanın havacılık, uçak bakım sektörü, uçuş emniyeti, havacilık sektöründe insan faktörü ve örgütsel davranış alanlarındaki literatüre katkı sağlayacağı düşünülmektedir.

\section{Kavramsal Çerçeve}

\subsection{Zaman Baskisı}

Zaman, geçmişten bugüne gelip, geleceğe doğru akıp giden kesintisiz bir süreçtir (Smith, 1998: 24). Soyut niteliği nedeniyle anlamakta bazen zorlandığımız zaman kavramı, günlük yaşantımızda vazgeçemediğimiz ve aktivitelerimizin gerçekleşmesine çerçeve çizen önemli bir olgudur (Sarıipek, 2016: 113). Zaman; tasarruf edilemeyen, ödünç alınamayan, kiralanamayan, satın alınamayan, çoğaltılamayan, sadece kullanılan ve kaybedilen bir kaynaktır (Eren, 2016: 78). Zaman kavramı, söz konusu bu özellikleri nedeniyle kıt ve değerli bir kaynak olduğundan, hem örgütler hem de bireyler tarafından iyi kullanılması gerekir. Bir örgütün mal ve hizmet üretebilmesi için gereken faaliyetleri için harcadığı süreyi ifade eden örgütsel zaman, iyi kullanılamadığı takdirde iş hayatında çalışanlar üzerinde baskı oluşturabilir (Karakoç, 1990: 35). Küreselleşme ve teknolojik değişimler nedeniyle günümüzün hızla değişen dünyasında zaman baskısı altında olmak ve telaş içinde hareket etmek, tüm bireylerde görülen giderek artan ve ortak bir algıdır.

Zaman baskısı, bir birey ya da çalışanın belirli bir görevi yerine getirebilmek için gereken zamanın az olması nedeniyle ortaya çıkan psikolojik bir durumdur. Bireyin dikkatini dağıtarak strese sokan bu durum, yapılması gereken işin yetersiz bir zamanda yapılması nedeniyle bireyde oluşan algının sonucudur (Çoban, 2019: 51). Bir işi tamamlamak için gerekli zamanın kıt olması nedeniyle ortaya çıkan zaman baskısı, örgütsel yaşamda yaygın olarak görülen bir olgu olarak, bireysel ve örgütsel performansı etkiler (Maruping vd., 2015: 1315). Zaman baskısı, bireyin belirli bir sürede tamamlaması gereken faaliyeti olağandan daha hızlı yapması için ortaya çıkan ve birey üzerine yüklenen bir taleptir (Malik, 2015: 2). Zaman baskısı, yapılacak bir faaliyetin zaman sınırlarının stresi tetiklemeye başladığı ve bireyin söz konusu bu stresle başa çıkma yollarına ihtiyaç duyduğunda ortaya çıkan bir algıdır (Ordonez ve Benson, 1997).

Zaman baskısı, bireyde psikolojik stres hissini artıran önemli bir çevresel faktördür. Zaman baskısının insan performansı üzerindeki etkisini özellikle önemli ve kritik kararların verildiği tıp, havacılık, kamu yönetimi, nükleer ve kimyasal santraller, finans kurumları ve bilişim örgütleri gibi birçok iş çevresinde yaygın olarak görmek mümkündür (Çoban, 2019: 52; Zakay, 1993: 60; Pietsch ve Messier, 2017: 51). Zaman baskısı altında, bilişsel kaynakların yetersizliği nedeniyle bireyin karmaşık görevlerdeki performansında düşme meydana gelir. Baskı altındaki birey karar verme sürecinde basit, doğrusal olmayan ve belirli kısa yolları içeren hissi yöntemleri kullanacağından bilgi işleme kapasitesinde azalma, önemli bilgilerin ihmal edilmesi, bilgileri filtre etmeye çalışma, önemli verileri unutma ve yanlış değerlendirme gibi olumsuz durumlar oluşabilir (Zakay, 1993: 60). Zaman baskısı, bireyi olması gerekenden daha hızlı davranması gerektiğine motive ederek, muhtemel karar stratejilerinin seçimini ve potansiyel çözüm arayışlarını sınırlar. Zaman baskısı altında karar vericiler, daha az bilgi kullanarak daha hızlı hareket etme eğilimindedirler. Bu nedenle ilk izlenimlerini revize etme şansları azdır ve iyi bildikleri sezgisel karar almaya yönelirler (Moore ve Tenney, 2012: 329).

Zaman baskısı ile ilgili yapılan çalışmaların büyük çoğunluğu, zaman baskısının karar verme sürecini negatif olarak etkilediğini ortaya koymaktadır. Çünkü zaman kısıtı nedeniyle karar vermeye çalışan bireyler, daha az seçeneği ve analitik süreçleri dikkate alarak karar vermeye çalışmaktadır. Bu durum da karar sürecinde olumsuz çıtılara neden olmaktadır. Çoğu insana göre, "hızlı karar kötü karar"dır (Ordonez vd., 2015: 522). Algılanan ve artan zaman baskısının, takım üyelerin yaratıcılığını negatif olarak etkilediği (Khedhaouria, 2017: 942); bireyin öz yeterliliğini düşürdüğü ve tükenmişlik seviyesini arttırdığı (Güran ve Güler, 2019: 153); karar verme sürecinde sıkça riskli alternatiflere yönelimi arttırdığı ve denetlenebilen bilgi miktarını azalttığı (Huber ve Kunz, 2007: 415); psikolojik stres ve fiziksel sorunlar ile sosyal hayatın düzeninin bozulmasına neden olduğu (Bozacı, 2019: 656); bilgi işleme motivasyonunu düşürdüğü için müzakere verimliliğini negatif olarak etkilediği (Dreu, 2003) ve öğrenmeye dayalı görevlerde performansı düşürdüğü (Cella vd., 2007: 164) görülmüştür.

Literatüre bakıldığında zaman baskısı ile ilgili yapılan araştırmaların farklı sonuçlarının olduğu da görülmektedir. Zaman baskısının, karar alma sürecinde alternatiflerin ilişkisel özelliklerine aşırı odaklanmanın ortaya çıkardığı bağlamsal etkileri azalttığı (Dhar vd., 2000); grup olarak karar verme sürecinin 
başlangıcında, üyelerin karar almaya odaklanmasına olumlu katkı yaptığı (Isenberg, 1981); kısa süreli zaman baskısının karar verme sürecine pozitif enerji sağladığı (Thayer, 1989); bazı durumlarda az miktardaki zaman baskısının daha yüksek verimliliğe ve yaratıcılığa katkı sağladığı (Ordonez vd., 2015: 5263) görülmüştür. Moore ve Tenney'e (2012: 313) göre, zaman baskısı bireyin performansını negatif olarak etkilemekle birlikte, belirli bir işe olması gerekenden fazla zaman ayırmak da performansın marjinal getirisini düşürebilir. Kısaca söylemek gerekirse, bireylerin yaşadığı zaman baskısı muhtemelen karar verme performansını olumsuz etkilemekle beraber, bu etki her koşulda geçerli olmayabilir.

\subsection{Teknostres}

Günümüz dünyasında her yanımızı saran bilgi ve iletişim teknolojileri, işlerimizi yaparken ve başkalarıyla iletişim kurarken hayatımızı son derece kolaylaştıran araçlardır. Modern teknoloji günlük hayatımıza önemli katkılar sağlamakta ve bizleri memnun etmekle birlikte, bazı yönleri ile de hayatımızda rahatsızlık, endişe, stres ve sorunlara yol açabilmektedir (Salanova, 2013: 422). İlk defa klinik psikoloğu Craig Brod tarafından 1980'li yılların başında ortaya konan teknostres kavramı, günlük yaşamda bireylerin bilgisayar teknolojileri ile etkileşimi sonucu ortaya çıkan stresi ve psikosomatik rahatsızlığı ifade etmektedir. Teknostres, yeni teknolojilerle sağlıklı bir şekilde başa çıkamamanın neden olduğu modern bir adaptasyon hastalığıdır (Brod, 1984). Teknostres, doğrudan ya da dolaylı olarak teknolojiye maruz kalmanın sonucu olarak insanın tutum, düşünce, davranış ve ruh halinde görülen negatif bir durumdur (Tacy, 2015: 6). Şahin ve Çoklar'a (2009: 1438) göre, teknoloji kullanımı nedeniyle bireylerde ortaya çıan tüm olumsuz etkilerin toplamı teknostres olarak tanımlanabilir. Teknostres kavramı, Brod (1984) tarafından tanımlanmasına rağmen, literatürde farklı araştırmacılar tarafından bu kavramın yerine kullanılan teknofobi, siberfobi, bilgisayar fobisi, bilgisayar stresi, bilgisayar kaygısı ve bilgisayardan kaçınma gibi kavramları da görmek mümkündür (Hudiburg, 1996).

Teknostres, örgüt ortamında bilgi ve iletişim teknolojilerinde birçok görevi yerine getirme çabası, sürekli olarak bu teknolojilere ulaşmaya ya da bağlanmaya çalışmak, aşırı bilgi yükü, sık sık sistem güncellemeleri, bu güncellemeler sonucunda ortaya çıan belirsizlik, sürekli yeniden öğrenme, buna bağlı işle ilgili güvensizlikler ve bilgisayar teknolojilerinin örgütsel kullanımı ile ilgili teknik sorunlar nedeniyle kullanıcıların yaşadığı stresi ifade eder (Tarafdar vd., 2011: 304). İş yaşamındaki hızlı değişim, teknolojik karmaşıklık, değişen teknolojiye uyum süreci, eğitim eksikliği, artan iş yükü, değişen iş rolleri, teknoloji kullanıcısının deneyimi ve yaşı, yönetim baskısı ve örgütsel çevre teknostresi etkileyen faktörler arasındadır (Şahin ve Çoklar, 2009: 1438; Türen vd., 2015: 4).

Günümüzün modern işletmelerinde bilgisayar sistemleri giderek artmakta ve işlerin çoğu bilgisayarlar aracılığı ile yapılmaktadır. Çalışanların bilgisayarlarla bu kadar yoğun etkileşim içinde olması, çalışanlarda diğer örgütsel faktörlere göre daha fazla stres yaratmaktadır. Bu stres klavyede yanlış bir tuşa basma, yapılan işi kaydetmeme, bilgi kaybı, sürekli bilgisayar ekranında beliren güncelleme ikazları vb. birçok etkenden kaynaklanmaktadır (Mahboob ve Khan, 2016: 30). Bilgi ve iletişim sistemleri, çalışanların sürekli olarak birbirleri ile bağlantı kurabilmelerini sağladığından dolayı, günlük iş saatinin uzamasına hatta mesai sonrasına sarkmasına neden olmaktadır. Çalışanlar e-posta, kablosuz ağlar ve farklı iletişim uygulamaları ile geleneksel çalışma şekillerinin dışında çalışabilmektedir (Ragu-Nathan vd., 2008: 421). Modern teknolojinin bu imkânlarının hayatın her anını doldurması, özel yaşamı baskı altına alması ve bireyleri sürekli bağlantı içinde olmaya zorlaması algılanan teknostresi arttırmaktadır.

Teknostresin boyutları denilebilecek ve teknostrese neden olan kaynaklar hakkında literatürde farklı araştırmaları görmek mümkündür. Brillhart (2004) tarafından teknostres dört boyut altında incelenmiştir. Bu boyutlar; teknoloji kullanıcılarının maruz kaldığı ve bilgi yorgunluğuna sebep olan aşırı teknolojik iş yükünü ifade eden veri sisi (data smog); bilgi ve iletişim sistemlerinde çoklu görevlerin aynı anda yapılabilmesi ile insan zihninin kapasitesi arasındaki çatışmayı ifade eden çoklu görev çılgınlığı (multitasking madness); virüs bulaşması, gereksiz mesajlar, sistem çökmesi, düşük performans gibi bilgisayar sorunları (computer hassles) ve çalışanın bilgisayar sistemleri ile çok fazla çalışması sonucu çalışanda oluşan duygusal tükenmeyi ifade eden tükenmişlik sendromu (burnout)'dur. Ennis (2005) tarafından kütüphane çalışanları üzerinde yapılan bir çalışmada teknostrese neden olan kaynaklar; değişim hızı, eğitim eksikliği, iş yükü, standardizasyon eksikliği, teknoloji eksikliği ve iş yerindeki roller olmak üzere altı boyut halinde ele alınmıştır.

Tarafdar vd. (2007: 315) tarafından yapılan çalışmada ortaya konan teknostres kaynakları, güçlü teorik ve ampirik yapısından dolayı literatürde en çok kabul gören teknostres boyutlardır. Araştırmacılar, bu boyutları 
teknolojik iş yükü, teknolojik istila, teknolojik karışıklık, teknolojik güvensizlik ve teknolojik belirsizlik olmak üzere beş boyut altında incelemişlerdir.

$>$ Teknolojik iş yükü, içinde bulunulan örgütsel koşullar nedeni ile üzerinde baskı hisseden bir çalışanın yaşadığı olumsuzluklar nedeniyle diğer çalışanlara göre daha hızlı ve uzun çalışması sonucu ortaya çıkar (Longinus vd., 2013: 103). Teknolojiyi yoğun olarak kullanan işlerde çalışanların birim zamanda yapması gereken iş miktarı artmakta, buna bağlı olarak daha fazla mental performans gerekmekte ve çalışan hata yapma riski arttığından dolayı stres yaşamaktadır (Türen vd., 2015: 5).

$>$ Teknolojik istila, bilgi ve iletişim teknolojilerinin hayatın her alanını işgal etmesinden dolayı iş ve aile yaşantısının birbirine girmesi sonucunda meydana gelen çatışmaları ifade eder (Chen, 2015: 68).

> Teknolojik karışıklık, bilgi ve iletişim çalışanlarının teknolojideki karışıklık nedeniyle yaşadığı yetersizliği tanımlar. Çalışanlar, kullandıkları teknolojinin çeşitli yönlerini anlamak, öğrenmek ve kullanmak için çaba harcamakta zorlanır (Ahmad vd., 2009: 1016; Tarafdar vd., 2007: 311).

$>$ Teknolojik güvensizlik, iş yerlerinde kullanılan otomasyon ve bilişim sistemlerinin gelişmesi nedeniyle çalışanların işlerini kaybetme riski ile karşı karşıya kalmasını ifade eder (Longinus vd., 2013: 103).

> Teknolojik belirsizlik, teknolojinin sürekli gelişimine ayak uyduramayan, geri kalan ve eğitim eksikliği hisseden çalışan üzerinde oluşan belirsizlik ve tedirginliktir (Tarafdar vd., 2007: 311).

Psikolojik bir sorun olan teknostres işyeri ortamına zarar verir, iş memnuniyetsizliğini artırır, çalışanın kendisine saygısını azaltır ve çeşitli hastalıkların ortaya çıkmasına neden olur (Longinus vd., 2013: 102). Teknostrese ait belirtiler, bireyin içinde bulunduğu duruma göre kendini gösteren çok çeşitli fizyolojik, psikolojik ve davranışsal değişiklikleri içerir. Bu değişiklikler olumsuz benlik algısı, negatif tutumlar, duygusal tükenme, diğer insanları düşünmeme ve his kaybı gibi şekillerde kendini gösterir. Uzun süreli stres, psikosomatik hastalığa neden olabilir (Nawe, 1995). Teknostresin fizyolojik belirtileri; yorgunluk, sirt ve omuz ağrısı, işten sonra gevşeyememe ve uyku güçlüğüdür. Bilinen en yaygın psikolojik belirtiler; panik, anksiyete, izolasyon hissi, hayal kırıklığı, bilgisayarlara karşı olumsuz tutum, sinirlilik, öfke, tükenme, artan hatalar, devamsızlık, düşük motivasyon ve konsantrasyon zorluğudur (Brod, 1984). Literatürde teknostresle ilgili yapılan çalışmalara bakıldığında teknostresin, tükenmişlik sendromunu arttırdığı, performans ve iş tatminini düşürdüğü (Yener, 2018: 98; Longinus vd., 2013: 100; Mahboob ve Khan, 2016: 30); bireysel iş rolü yükünü arttırdığı ve verimliliği azalttığı (Tarafdar vd., 2007: 302); ilerleyen yıllarda sosyal refahı tehdit ettiği (Nimrod, 2018: 1080); örgütsel sinizmi (Çelik ve Özdemir, 2016: 256); çalışanların rol çatışmasını pozitif olarak etkilediği ve özel hayatını baskı altına aldığı (Tu vd., 2005: 80) görülmüştür.

İşletmeler, çalışanların kişilik özelliklerine uygun çeşitli eğitim fırsatları sunarak çalışanların teknostres ile mücadele edebilmesini sağlayabilir. Bunun için, işletmelerin yeni bir teknolojik sisteme geçiş yaparken başarılı bir geçiş planı oluşturması ve uygulaması gerekmektedir (Sanderlin, 2004). Teknolojiyi yoğun kullanan işyerlerinde çalışanlara müzik dinletmek, çalışma ortamının mümkün olduğunca sakin kalmasını sağlamak, egzersiz yapmak, çalışanların belirli saatlerde sessiz bir ortamda dinlenmelerini sağlamak, ara sıra bilgisayarların olduğu ortamdan uzaklaşmak, kullanımı kolay yazılımları seçmek teknostresi azaltmak için alınabilecek bireysel ve örgütsel tedbirler arasında sayılabilir (Akınoğlu, 1993: 168).

\subsection{Havacılık Sektöründe Zaman Baskısı ve Teknostres İlişkisi}

Globalleşme ve teknolojik gelişmelere bağlı olarak büyük bir hızla büyüme eğilimi içinde olan havacılık sektörü, tüm dünyada yolcu ve kargo taşımacılığındaki payını giderek arttırmaktadır. Teknoloji kullanımı ve değişiminin önemli olduğu havacılık sektörü, hem sivil hem de askeri alanda yaratmış olduğu ekonomik ve stratejik değer sebebiyle her ülke için itibar kaynağıdır. Kara, deniz ve demir yolları ile karşılaştırıldığında daha güvenilir olan havacılık sektöründe faaliyetler, ciddi güvenlik ve emniyet kuralları çerçevesinde yürütülür. Havacıllk sektöründe emniyetli ve kazasız uçuş faaliyetlerinin icra edilmesine katkı sağlayan en önemli faktörlerin başında uçak bakım faaliyetleri gelmektedir (Çoban, 2019: 46). Uçak bakım faaliyetleri, küresel havacilık endüstrisinin önemli bir bileşenidir. Bakım faaliyetleri zaman baskısı, minimum geri bildirim ve zor koşullarda farklı görevlerin yapıldığı karmaşık bir sistem içinde icra edilir (Yazgan ve Kavsaoğlu, 2017: 97). Havacılık sektöründe uçuş emniyetinin vazgeçilmez bir parçası olan ve doğru, planlı ve belirli bir zaman çerçevesinde yapılması gereken uçak bakım faaliyetleri insan, malzeme, teçhizat ve teknoloji gibi birçok önemli girdiyi kapsar. Bakım teknisyenleri tarafından yürütülen söz konusu kollektif faaliyetler, belirli kurallar kapsamında emniyetli bir uçuşun gerçekleştirilmesine yöneliktir (Çoban, 2017: 89-90). Hem 
havacılık sektörünün genelinde hem de uçak bakım sektöründe insan faktöründen kaynaklanan ve istem dışı olarak meydana gelen insan hataları vardır. İnsanlar, alt sistemlerden oluşan bir sisteme benzeyen, hata yapma ihtimali olan ve belirli tolerans seviyesine sahip organik yapılardır. Bu nedenle, insanlar bazı koşullar altında normal davranışlarından farklı olan ve negatif olarak görülen hatalar yapabilir (Latorella ve Prabhu, 2000: 134). İnsan faktörü, havacılık ve uçak bakım sektöründe bir çalışanın görevini yaparken kasıtsız olarak yapılan, genellikle örtük ve sonucunda bir zararın oluştuğu insan hatalarını ifade eder (Virovac vd., 2017: 257).

1988 yılında Hawai'de iç hat uçuşu gerçekleştiren 19 yaşındaki Boeing 737 tipi uçağın gövdesinin parçalanması sonucu meydana gelen kaza, uçak bakım sektöründe insan faktörü hataların çok ciddi ve ölümcül sonuçlar doğurabileceğini ortaya koyması açısından önemlidir (Taylor, 2000: 202). Bu kazadan sonra, 1990'lı yılların başından itibaren uçak bakım sektöründe insan faktörü kaynaklı hataların sebeplerini araştırmak için çalışmalar yapılmıştır. Bu çalışmalar içinde en dikkat çekici olanı, Transport Canada firması çalışanı Gurdon Dupont tarafından 1993 yılında geliştirilen “Kirli Düzine (Dirty Dozen)" modelidir. Bu modele göre, uçak bakım çalışanlarının hata yapmasına neden olan 12 temel faktör; iletişim eksikliği, gönül rahatlığı, bilgi eksikliği, dikkat dağılması, takım çalışması eksikliği, yorgunluk, kaynak yetersizliği, katılım eksikliği, farkındalık eksikliği, yıkıcı işyeri normları, zaman baskısı ve strestir (Çoban, 2019: 48).

Havacılık sektöründe, planlı uçuşları zamanında gerçekleştirebilmek amacıyla periyodik bakımların zamanında yapılması, plansız arızaların hemen giderilmesi ve uçağın bir an önce uçuşa verilmesi gerekir. Ekonomik kriz dönemlerinde maliyetleri düşürmek için hava yolu işletmeleri uçakların uzun süre bakımda kalması yerine daha yoğun uçmasını tercih eder. Bu gibi ticari kaygılar nedeniyle, uçak bakım sektörü sürekli zaman baskısı altındadır (Yazgan ve Kavsaoğlu, 2017: 100). Ticari sivil havacılığın yanı sıra askeri havacılıkta da zaman baskısı, önemli bir stres kaynağıdır. Harbe hazırlığı en üst seviyede tutmak amaciyla yapılan eğitim uçuşları, ansızın ortaya çıkan güvenlik risklerini etkisiz hale getirmek amacıyla yapılan harekât uçuşları ve potansiyel risklere karşı personel, uçak ve malzeme olarak destek verme ihtiyacı askeri uçak bakım faaliyetlerinde zaman baskısını önemli bir olgu haline getirmektedir (Çoban, 2019: 54).

Hem sivil hem de askeri havacılık sektörü, teknolojinin yoğun olarak kullanıldığı sektörlerin başında gelmektedir. Havacılık sektöründe en son teknoloji ile çalışan uçak, helikopter, insansız hava aracı ve malzemeleri görmek mümkündür. Bu teknolojik gelişmelere bağlı olarak uçak bakım faaliyetleri yıllar içinde değişmiştir. Uçak bakım faaliyetlerinin doğru ve aksatılmadan yapılması için birçok teknolojik malzeme ve ekipman sıklıkla kullanılır. Bununla birlikte, bu faaliyetlerin merkezinde bakım teknisyeni yani "insan" vardır (Padil vd., 2018: 1). Teknolojik gelişmeler ışığında ortaya çıkan arıza belirleme sistemleri, iyileştirilmiş donanımlar, etkin yazılımlar ile daha iyi bakım ekipmanı ve yöntemleri bakım personelinin iş yükünü azaltmış ve uçuş emniyetine katkı sağlamıştır. Bununla birlikte söz konusu teknolojik değişimler ve yenilikler, bakım teknisyenlerinde yeni beceri ve bilgi edinmeyi gerektirdiğinden insan faktörü kaynaklı hatalara sebep olabilir (Reason ve Maddox, 1995). Türen vd.'ne (2015: 8) göre, uçuş sırasında karmaşık cihazları belirli bir sıra dâhilinde kontrol etmek, bu cihazları güncellemek ve meydana çıkabilecek arızalar pilotlarda; ileri teknoloji ürünü hava araçlarının elektronik yazılımlarının yüklenmesi, bakımı, kontrolü ve güncellenmesi de bakım teknisyenlerinde teknostres yaratabilir.

Bahsedildiği gibi havacılık ve uçak bakım sektörü teknolojinin yoğun kullanıldığı sektörler olduğundan bakım teknisyenleri, bakım faaliyetleri sırasında kullanılan teknolojik malzemeler, bakım kayıtlarının yapılması ve takibi için gerekli bilgisayar sistemleri ve iletişim araçları nedeniyle teknolojik iş yükü ve karmaşıklığa maruz kalabilir. Bu durum da çalışanlarda teknostresin ortaya çıkmasına neden olabilir. Alam (2016: 62) tarafından Pakistan'da pilot ve bakım teknisyenleri üzerinde yapılan bir araştırmada çalışanların işteki rollerine ait iş yükü aşırı şekilde arttığında, teknostresin takım verimliliğini negatif olarak etkilediği görülmüştür. Araştırmacıya göre havacılık sektöründeki teknolojik gelişmeler, verimliliği arttırmakla birlikte aynı zamanda stres kaynağıdır. Türen vd. (2015: 8-15) tarafından bankacılık ve havacılık sektöründe (pilot, bakım teknisyeni ve yer personeli) yapılan bir araştırmada bankacılık sektörü çalışanlarının \%36'sının, havacılık sektörü çalışanlarının \%32'sinin teknostres yaşadığı görülmüştür.

Cheng'e (2018: 123) göre hava yolu işletmeleri kâr elde edebilmek amacıyla, uçakları uçuşa hazır bir şekilde tutmak ve uçuş iptal/gecikmelerinin önüne geçebilmek için zaman baskısı altında bakım faaliyetlerini yerine getirirler. Zaman baskısıyla birlikte sektörde görülen hızlı teknolojik değişim, bakım teknisyenlerini strese sokabilir. Ariely ve Zakay (2001: 187), zaman baskısı altındaki karar vericilerin karar sürecinin tüm adımlarını 
tamamlayamadıklarını ve bilişsel hatalar yaptığını; Hendy vd. (2001), zaman baskısının çalışanın iş yükünü, performansını ve hata miktarını etkileyen temel bir stres kaynağı olduğunu; Moray (1980), zaman baskısının çalışanın sübjektif iş yükünü arttırdığını; Paola ve Gioia (2016), zaman baskısının akıl yürütme sürecini negatif olarak etkilediğini, bireylerde önemli bilgileri görmezden gelme ve sezgisel karar verme eğilimini arttırdığını ifade etmiştir. Hammond (2000: 83) tarafından ortaya konan bilişsel süreç teorine (cognitive continuum theory) göre; bireylerin verdiği kararlar, duruma göre sezgisel ya da analitik olabilir. Sezgisel kararlarda örüntü eşleştirme ve geçmiş deneyimlere yönelme; analitik kararlarda ise daha kapsamlı bir değerlendirme süreci vardır. İyi bir karar, karar stratejisi ile görev arasındaki uyum sonucu ortaya çıkar. Analitik süreçler, karar vericinin kullanabileceği ipuçları ve alternatiflere dayanan iyi yapılandırılmış kararların ortaya çıkmasını sağlarken; sezgisel kararlarda bundan bahsetmek zordur. Zaman baskısı altında çalışan bakım teknisyenlerinin işlerini yaparken belirli bir değerlendirme sürecine dayanan ve daha çok zaman gerektiren analitik kararlar yerine, sezgisel kararlara yönelmeleri muhtemeldir. Literatürdeki çalışmalar doğrultusunda, havacılık sektöründe ticari kaygılar ve yoğun teknoloji kullanımı nedeniyle uçak bakım faaliyetlerinde zaman baskısı ve teknostresin bakım teknisyenlerinin performansını etkileyebilecek iki önemli kavram olduğunu ve bu iki kavramın birbiriyle ilişkili olduğunu söylemek mümkündür.

$\boldsymbol{H}_{1}$ : Bakım teknisyenlerinin algıladığı zaman baskısı ile teknostres arasında anlamlı pozitif bir ilişki vardır.

Tarafdar vd.'ne (2007: 309) göre; bilgisayar ve iletişim teknolojileri, çalışanların aynı anda birden fazla işi yapmasını mümkün kılar. Eş zamanlı çoklu görevlere ve teknolojik iş yüküne maruz kalmak, çalışanlarda bazı işlerin bitmemiş olduğu hissini uyandırır ve bu görevlerin tamamlanması için daha fazla zamana ihtiyaç vardır. Eğer yeterli zaman yoksa çalışanın konsantrasyonu bozularak, tükenmişlik ve aşırı iş yükü ile birlikte teknostres ortaya çıkar. Bachiller (2001) tarafından kütüphane çalışanları üzerinde yapılan bir araştırmada; çalışanların bilgisayar kullanma yetersizliği, bilgisayar problemiyle ilgili yardım eksikliği, yavaş program ve bilgisayar hızı ile artan zaman baskısı nedeniyle teknostres yaşadığı ve çalışanlarda sırt ağrıları, göz yorgunluğu, baş ağrısı, artan nabız, aşırı ekran görüntüsüne maruz kalma, öfke ve isteksizlik gibi fiziksel ve psikolojik sorunların ortaya çıktığı görülmüştür. Çoban'a (2019: 52) göre, uçak bakım sektöründe planlı iş yükünü belirli bir zaman sınırlaması içinde yapma mecburiyeti bakım teknisyenlerinin iş yükünün artmasına, bazı iş basamaklarının atlanarak kalite standartlarının düşmesine, yorgunluğa, strese ve istenmeyen insan faktörü hatalarına neden olabilir. Bu kapsamda hem sivil hem de askeri havacılık sektöründe uçak bakım faaliyetlerinin icrasında yaşanan zaman baskısının, teknoloji ile iç içe çalışan ve aynı anda birçok teknolojik çoklu görev ve iş yüküne maruz kalan bakım teknisyenlerinin algıladığı teknostresi pozitif olarak etkileyebileceğini söylemek mümkündür.

\section{$\mathrm{H}_{2}$ : Zaman baskısı, bakım teknisyenlerinin algıladığı teknostresi pozitif olarak etkiler.}

Literatüre bakıldığında demografik özelliklere göre bireylerin hissettiği zaman baskısı ve teknostresin farklılık gösterdiği görülmektedir. Earles vd. tarafından (2004: 285) yapılan bir araştırmada; zor ve zaman baskısının olduğu bilişsel görevlerin yerine getirilmesinde, yaşlı bireylerin performansları hakkında endişeli olduğu ve kendileri hakkında negatif bir öz değerlendirme yaptığı görülmüştür. Paola ve Gioia (2014: 1) tarafından İtalya'da üniversite öğrencileri üzerinde yapılan bir araştırmada, zaman baskısı kız öğrencilerin sözlü ve sayısal görev performanslarını olumsuz olarak etkilerken; erkek öğrencilerin performansında anlamlı bir değişiklik olmadığı görülmüştür. Shurchkov'a (2012) göre; belirli rekabet ortamlarında kadınları erkeklerden daha az etkili kılan faktörlerden biri, kadınların zaman baskısı ile başa çıkabilme kabiliyeti ile ilgilidir. Gunthorpe ve Lyons'a (2004: 208) göre yaş, cinsiyet, aile tipi, haftalık çalışma saati gibi demografik özellikler, zaman baskısını yordayan önemli faktörlerdir.

Teknostres konusunda kapsamlı ve dikkat çekici çalışmalar yapan Tarafdar vd.'ne (2011: 119-120) göre, cinsiyet ve bilgisayar deneyimi, teknostres üzerinde etkili olan iki demografik özelliktir. Genellikle kadınlar, erkeklere göre teknoloji kullanımında zorluk yaşar ve teknolojiyi zorunlu durumlarda kullanır. Erkekler ise teknolojiye meyilli ve isteyerek teknolojiyi kullanır. Bundan dolayı erkekler daha fazla teknolojik karmaşıklı̆a ve yoğunluğa maruz kaldıklarından, kadınlara göre daha fazla teknostres hisseder. Bilgisayar ve teknoloji kullanım tecrübesi olan çalışanlar daha az teknostres yaşarlar. Çünkü onlar, teknostresin ortaya çıardığ 1 problemlerle başa çıkabilecek deneyime sahiptir. Daha fazla iş tecrübesine sahip yaşlı çalışanların genel olarak stresle başa çıkma yetenekleri yüksektir. Bununla birlikte eğitim seviyesi arttıkça teknoloji kullanımı artan bireylerin, teknolojiye uyumu artacağından teknostres seviyeleri düşük olabilir. Owusu-Ansah vd. (2016: 232) 
tarafından Gana'da banka çalışanları üzerinde yapılan bir araştırmada, erkek çalışanların kadın çalışanlara göre daha fazla teknostres hissettiği görülmüştür. Türen vd. tarafından (2015: 13) bankacılık ve havacilık sektöründe yapılan araştırmada, yaş ile teknostres ve alt boyutları arasında anlamlı bir ilişki olmadığı; kadın çalışanların erkeklere göre daha fazla teknolojik belirsizlik yaşadığı; eğitim seviyesi ve görev ünvanlarına göre çalışanların teknolojik iş yükü, belirsizlik ve karmaşıklık algısının değiştiği görülmüştür. Bahsedilen çalışmalar ışığında havacılık sektöründe demografik özelliklere göre bakım teknisyenlerinin zaman baskısı ve teknostres algısının farklı olabileceği söylenebilir.

$H_{3}$ : Demografik özelliklere göre bakım teknisyenlerinin zaman baskısı algısı farklıdır.

$\mathrm{H}_{4}$ : Demografik özelliklere göre bakım teknisyenlerinin teknostres algisı farklıdır.

\section{Yöntem}

\subsection{Araştırmanın Amacı ve Önemi}

Bu araştırmanın amacı, havacılık sektöründe zaman baskısının teknostrese etkisini ve demografik özelliklere göre bakım teknisyenlerinin zaman baskısı ve teknostres algısının farklılık gösterip göstermediğini incelemektir. Literatüre bakıldığında dünyada ve Türkiye'de hızlı bir şekilde gelişmekte olan havacılık sektöründe zaman baskısı ve teknostres kavramlarının insan faktörü ve uçuş emniyeti konularını ilgilendiren iki önemli olgu olduğu; havacılık sektöründe söz konusu iki kavramla ilgili çalışmaların sınırlı olduğu; bu kapsamda araştırmanın havacılık sektöründe ilgili literatüre katkı yapacağı düşünülmektedir.

\subsection{Araştırmanın Modeli ve Hipotezler}

Literatür taraması ışığında geliştirilen araştırma modeli (Şekil 1) ve hipotezler aşağıda sunulmuştur.

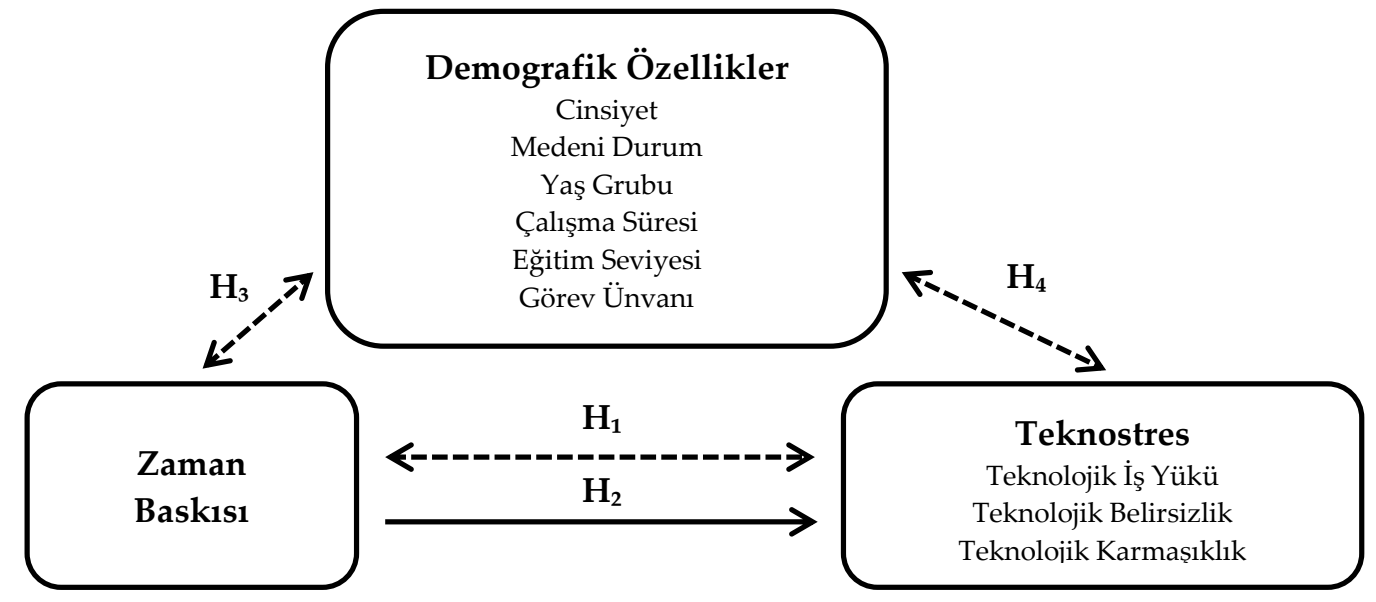

Şekil 1. Araştırma Modeli

$\mathbf{H}_{1}$ : Bakım teknisyenlerinin algıladığı zaman baskısı ile teknostres arasında anlamlı pozitif bir ilişki vardır.

$\mathbf{H}_{2}$ : Zaman baskısı, bakım teknisyenlerinin algıladığı teknostresi pozitif olarak etkiler.

$\mathbf{H}_{3}$ : Demografik özelliklere göre bakım teknisyenlerinin zaman baskısı algısı farklıdır.

$\mathbf{H}_{4}$ : Demografik özelliklere göre bakım teknisyenlerinin teknostres algısı farklıdır.

\subsection{Yöntem}

\subsubsection{Evren ve Örneklem}

Araştırmanın evrenini, Malatya ilinde kamu sektöründe çalışan uçak ve helikopter bakım teknisyenleri oluşturmaktadır. Araştırma kapsamında belirlenen evrenden ( $\mathrm{N}=322)$ gerekli olan asgari örneklem büyüklüğü, \%95 güvenirlilik düzeyi ve $\% 5$ hata payı dikkate alınarak $(\mathrm{n}=\mathrm{n} 0 / 1+\mathrm{n} 0 / \mathrm{N})$ formülü ile 175 bakım teknisyeni olarak hesaplanmıştır (Gürbüz ve Şahin, 2017: 129). 2018 yılı sonunda yapılan veri toplama sürecinde evrendeki tüm teknisyenlere kolayda örnekleme yöntemiyle elden anket formu dağıtılmıştır. Kolayda örnekleme, araştırmacılar tarafından ihtiyaç duyulan örneklem büyüklüğüne ulaşabilmek amacıyla evren içindeki en kolay ve ulaşılabilir deneklerden ucuz ve hızlı veri toplama imkânı sağladığından sosyal bilim araştırmalarında yaygın olarak kullanılmaktadır (Gürbüz ve Şahin, 2017: 132). Veri toplama süreci sonunda 184 adet anket formu toplanmıştır. 184 anket formundan geçersiz olan 7 adeti eksik ve geçersiz olduğundan 177 adet anket formu analize tabi tutulmuştur.

\subsubsection{Veri Toplama Araçları}


Araştırmada veri toplama aracı olarak anket yöntemi kullanılmıştır. Anket; demografik özellikler (6 soru), teknostres (14 soru) ve zaman baskısı (13 soru) ölçeği olmak üzere üç bölüm ve 33 sorudan oluşmaktadır. Teknisyenlerin teknostres algısını ölçmek amacıyla 3 boyutlu (teknolojik iş yükü: 5 soru; teknolojik belirsizlik; 4 soru; teknolojik karmaşıklık: 5 soru) ve 14 sorudan oluşan teknostres ölçeği kullanılmıştır. Bu ölçek, Alam (2015) tarafından Pakistan' da havacılık sektöründe yapılan bir araştırmada kullanılmış olup, Türen vd. (2015) tarafından havacılık ve bankacılık çalışanları üzerinde yapılan başka bir araştırmada Türkçe'ye uyarlanarak kullanılmıştır. Bu araştırmada, "teknolojik istila" boyutunun çalışanın özel hayatı; "teknolojik güvensizlik" boyutunun ise çalışanın ve örgütün sosyal dinamikleri ile ilişkili olması ve her iki boyutun çalışanın işyerinde yaşadığı teknostresle doğrudan ilişkili olmaması gerekçesiyle söz konusu iki boyut araştırma kapsamı dışında bırakılmıştır. Bu nedenle teknolojik istila ve güvensizlik boyutları bu araştırmada da kullanılmamıştır. Ölçeğin güvenilirlik katsayısı, Alam (2015) tarafından yapılan araştırmada 0,80; Türen vd. (2015) tarafından yapılan araştırmada ise 0,85 olarak görülmüştür. Teknisyenlerin zaman baskısı algısını ölçmek amaciyla tek boyutlu ve 13 sorudan oluşan zaman baskısı ölçeği kullanılmıştır. Bu ölçek, Torlak vd. (2013) tarafından üniversite öğrencileri üzerinde yapılan araştırmada Türkçe'ye uyarlanarak kullanılmıştır. Bu araştırmada ölçeğin güvenilirlik katsayısı 0,80 olarak görülmüştür. Ölçeklerdeki sorulara verilecek cevaplar, 5'li Likert (1: Kesinlikle Katılmıyorum, 2: Katılmıyorum, 3: Kararsızım, 4: Katılıyorum, 5: Tamamen Katılıyorum) yöntemine göre hazırlanmıştır.

\subsection{3. İstatistiksel Analiz}

Araştırmada verilerin hazırlık ve analiz aşamasında SPSS 21.0 ve AMOS 24 programları kullanılmıştır. Verilerin analizine başlamadan önce verilerin normal dağılım gösterip göstermediğini test etmek için basıklık ve çarpıklık analizi yapılmıştır. Veriler değerlendirilirken frekans, yüzde, ortalama ve standart sapma gibi tanımlayıcı istatistiksel yöntemler kullanılmıştır. Ölçeklerinin geçerliliğini ölçmek için AMOS 24 programı ile doğrulayıcı faktör analizleri; güvenilirliğini ölçmek için Cronbach Alfa katsayısı kullanılmıştır. Hipotez testlerinde parametrik testlerden olan Pearson korelasyon, basit doğrusal regresyon, T-testi ve tek yönlü varyans analizi (ANOVA) kullanılmıştır. Araştırmada verilerin analiz sonuçları, \%95'lik güven aralığında ve $\mathrm{p}<, 05$ istatistiksel anlamlılık düzeyinde değerlendirilmiştir.

\subsection{Bulgular}

\subsubsection{Demografik Özelliklere Ait Bulgular}

Tablo 1. Katılımcılara Ait Demografik Özellikler

\begin{tabular}{|c|c|c|c|c|c|c|c|}
\hline $\mathrm{N}=177$ & Gruplar & Say1 & $\%$ & & Gruplar & Say1 & $\%$ \\
\hline \multirow{3}{*}{ Cinsiyet } & Kadın & - & - & \multirow{3}{*}{ Medeni Durum } & Evli & 146 & 82,5 \\
\hline & Erkek & 177 & 100 & & Bekâr & 31 & 17,5 \\
\hline & $20-27$ & 19 & 10,7 & & Lise & 2 & 1,1 \\
\hline \multirow{4}{*}{ Yaş } & $28-35$ & 90 & 50,8 & \multirow{4}{*}{ Eğitim Durumu } & Yüksekokul & 39 & 22 \\
\hline & $36-42$ & 48 & 27,2 & & Lisans & 125 & 70,7 \\
\hline & $43-49$ & 18 & 10,2 & & Yük. Lisans & 9 & 5,1 \\
\hline & $50-56$ & 2 & 1,1 & & Doktora & 2 & 1,1 \\
\hline \multirow{6}{*}{ Çalışma Süresi } & 3 yıldan az & 9 & 5,1 & \multirow{6}{*}{ Görev Ünvanı } & & \multirow{3}{*}{169} & \multirow{3}{*}{95,5} \\
\hline & 3-8 & 19 & 10,7 & & & & \\
\hline & $9-14$ & 57 & 32,2 & & Teknisyen & & \\
\hline & $15-20$ & 54 & 30,5 & & Teknik Kontrol & 8 & 4,5 \\
\hline & $21-25$ & 26 & 14,7 & & & & \\
\hline & 25 yildan fazla & 12 & 6,8 & & & & \\
\hline
\end{tabular}

Tablo 1 incelendiğinde araştırmaya katılan bakım teknisyenlerinin hepsinin erkek olduğu; teknisyenlerin çoğunluğunun evli (\%82,5), 28-42 yaş grubunda (\%77,9), yüksekokul ve lisans mezunu (\%92,6) ve 9-25 yıl arası 
çalışma süresine $(\% 77,4)$ sahip olduğu görülmüştür. Bakım teknisyenlerinin büyük çoğunluğunun teknisyen $(\% 95,5)$, çok azının $(\% 4,5)$ ise teknik kontrol pozisyonunda görev yaptığ görülmüş̧ür.

\subsubsection{Geçerlilik ve Güvenilirlik Analizleri}

Araştırma ölçeklerinin yapısal geçerliliğini ölçmek amacıyla AMOS 24 programı kullanılarak doğrulayıcı faktör analizi (DFA) yapılmıştır. DFA, daha önceden kullanılan ölçeklerin özgün yapısının ve kuramsal evrende varsayılan ilişkilerin toplanan verilerle doğrulanıp doğrulanmadığını test etmek amacıyla sosyal bilimler araştırmalarında kullanımı giderek artan bir analizdir (Gürbüz ve Şahin, 2017: 340). Yapılan ilk DFA'da teknostres ölçeğinin 14. sorusunun (Çalıştığım yerde kullandığım teknoloji konusunda bana göre daha bilgili iş arkadaşlarım vardır.) faktör yükü $(0,12<0,32)$ ve zaman baskısı ölçeğinin ilk sorusunun (İşyerinde çoğu zaman etrafımdaki kimselerin beklentilerini karşılayamam.) sorusunun faktör yükü $(0,23<0,32)$ düşük çıtığından (Gürbüz ve Şahin, 2017: 317), söz konusu sorular ölçeklerden çıkartıldıktan sonra her iki ölçek için ikinci DFA yapılmıştır. DFA sırasında ölçeklerin faktör yapılarına ait uyum indekslerinin literatürde kabul gören eşik değerlerin içinde olması amacıyla sınırlı sayıda ve aynı faktör içinde olmak üzere bazı düzeltmeler (modifikasyon) yapılmıştır. DFA sırasında hangi uyum değerlerinin güvenilir olduğu konusunda literatürde tartışmalar devam etmekle birlikte, güncel araştırmalar 1şığında $x^{2} / d f$, RMSEA, SRMR ve CFI indekslerinin rapor edilmesinin yeterli olduğu belirtilmiştir (Gürbüz, 2019: 34). Yapılan DFA diyagramları Şekil 1 ve Şekil 2'de, uyum indekslerinin eşik değerler (Gürbüz, 2019: 34; Meydan ve Şeşen, 2015: 37) ile karşılaştırılması Tablo $2^{\prime}$ de sunulmuştur.
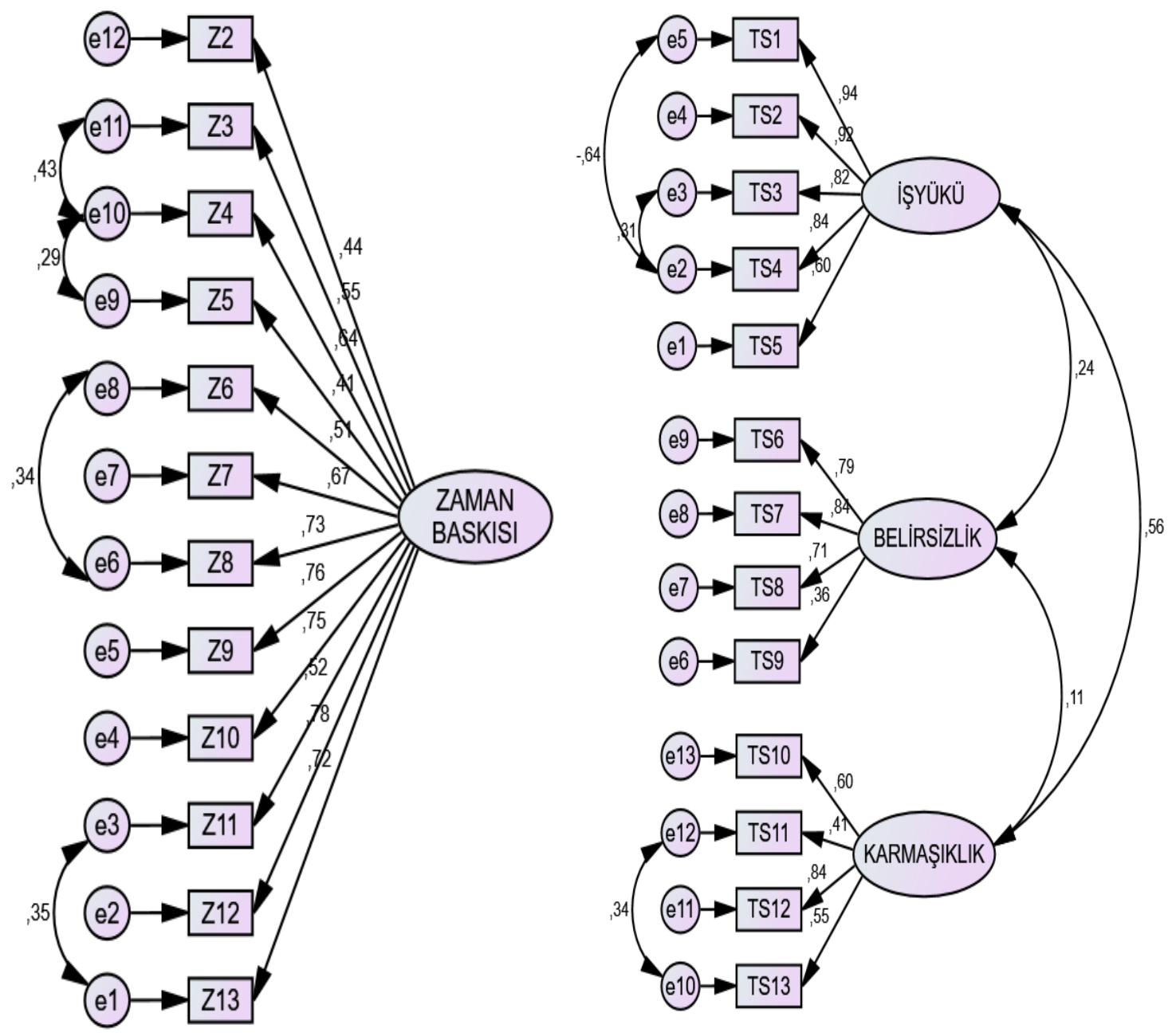

Şekil 2. Zaman Baskısı Ölçeği DFA Diyagramı

Şekil 3. Teknostres Ölçeği DFA Diyagramı

Tablo 2. Ölçeklerin Faktör Yapılarına Ait Uyum İndekslerinin Eşik Değerler İle Karşılaştırılması 
R. Çoban - T. Aydoğdu 12/3 (2020) 2442-2460

\begin{tabular}{|c|c|c|c|c|c|c|}
\hline \multirow{2}{*}{$\begin{array}{c}\text { Uyum } \\
\text { İndeksleri }\end{array}$} & \multicolumn{2}{|c|}{ Eşik Değerler } & \multirow{2}{*}{$\begin{array}{c}\text { Zaman Bask1S1 } \\
x^{2}=112,311 / d f=59 \\
p=, 000\end{array}$} & \multirow{2}{*}{$\begin{array}{c}\text { Uyum } \\
\text { Durumu }\end{array}$} & \multirow{2}{*}{$\begin{array}{c}\text { Teknostres } \\
x^{2}=123,487 / d f=50 \\
p=, 000\end{array}$} & \multirow{2}{*}{$\begin{array}{c}\text { Uyum } \\
\text { Durumu }\end{array}$} \\
\hline & İyi & Kabul & & & & \\
\hline $\mathbf{x}^{2 / d f}$ & $<3$ & $3<\mathrm{x}^{2} / \mathrm{df}<5$ & 2,47 & İyi & 1,90 & İyi \\
\hline RMSEA & $<, 050$ & $<, 080$ & ,091 & Düşük & ,072 & Kabul \\
\hline SRMR & $<, 050$ & $<, 080$ & ,063 & Kabul & ,066 & Kabul \\
\hline CFI & $>, 950$ & $>, 900$ & ,921 & Kabul & ,954 & İyi \\
\hline
\end{tabular}

Tablo 2'deki eşik değerlere göre ölçeklerin uyum indeksleri karşılaştıııldığında teknostres ölçeğine ait uyum indekslerinin ( $x^{2} / \mathrm{df}: 1,90$; RMSEA: ,072; SRMR: ,066; CFI: ,954) iyi ve kabul edilebilir olduğu; zaman baskıs1 ölçeğine ait uyum indekslerinin ( $x^{2} / \mathrm{df}: 2,47$; SRMR: ,063; CFI: ,921) iyi ve kabul edilebilir; ancak RMSEA (,091) indeks değerinin düşük olduğu görülmüştür. Bazı araştırmacılara göre; ,080-0,1 arasındaki RMSEA değeri "vasat" olmakla birlikte kabul edilebilir bir değerdir. 0,1'in üzerindeki değerler ise zayıf olarak yorumlanır (Gürbüz ve Şahin, 2017: 344; MacCallum vd., 1996: 134; Cangur ve Ercan, 2015: 157; Meral ve Takunyac1, 2016: 100; Maulana ve Rufaidah, 2014: 201). Yapılan DFA'lar sonucunda zaman baskısı ve teknostres ölçeklerinin yapısal geçerliliğinin doğrulandığını ve sonuçların her iki örneklemden toplanan veriler ile uyum içinde olduğunu söylemek mümkündür.

Zaman baskısı ve teknostres ölçeği ile teknostresin alt boyutlarına ait iç tutarlılığı ölçmek amacıyla yapılan güvenilirlik analizi Tablo 3'de sunulmuştur. Analiz sonuçlarına bakıldığında zaman baskısı $(\alpha:, 890)$ ve teknostres $(\alpha:, 839)$ ölçekleri ile teknostresin teknolojik iş yükü alt boyutunun $(\alpha:, 912)$ güvenilirliğinin yüksek; teknostresin teknolojik belirsizlik $(\alpha:, 769)$ ve teknolojik karmaşıklık $(\alpha:, 727)$ alt boyutlarının güvenilirliğinin kabul edilebilir seviyede olduğu görülmüştür (İslamoğlu ve Alnıaçık, 2014: 283).

Tablo 3. Güvenilirlik Analizi

\begin{tabular}{cccccc}
\hline & $\begin{array}{c}\text { Zaman } \\
\text { Baskısı }\end{array}$ & Teknostres & $\begin{array}{c}\text { Teknolojik } \\
\text { İş Yükü }\end{array}$ & $\begin{array}{c}\text { Teknolojik } \\
\text { Belirsizlik }\end{array}$ & $\begin{array}{c}\text { Teknolojik } \\
\text { Karmaşıklık }\end{array}$ \\
\hline Cronbach Alfa Değeri $\boldsymbol{\alpha}$ &, 890 &, 839 &, 912 &, 769 &, 727 \\
\hline
\end{tabular}

\subsubsection{Verilerin Normal Dağılım Testi}

Araştırmanın hipotez testlerine geçmeden önce kullanılacak uygun analiz yöntemlerini belirlemek için, araştırma ölçekleri ile toplanan verilerin normal dağılım gösterip göstermediği incelenmiştir. Bir verinin normal dağılım gösterip göstermediği farklı yollarla ölçülebilir. Bu yollardan biri, verilerin çarpıklık (skewness) ve basıklık (kurtosis) değerlerine bakmaktır (Gürbüz ve Şahin, 2017: 212). Normal bir dağılımda bu değerler, $-1,5$ ve $+1,5$ arasında yer almalıdır (Tabachnick ve Fidell, 2013). Bu nedenle verilerin normal dağılım testi için, verilerin çarpıklık ve basıklık değerlerine bakılmış ve Tablo 4'de sunulmuştur. Tablo 4 incelendiğinde her iki ölçek ile toplanan verilerin çarpıklık ve basıklık değerlerinin $-1,5$ ve $+1,5$ arasında olduğu ve normal dağılım gösterdiği görülmüştür. Bu nedenle hipotez testlerinde parametrik testlerden olan Pearson korelasyon, basit doğrusal regresyon, T-testi ve ANOVA testi kullanılmıştır.

Tablo 4. Verilerin Basıklık ve Çarpıklık Değerleri

\begin{tabular}{lccccc}
\hline & $\begin{array}{c}\text { Zaman } \\
\text { Baskısı }\end{array}$ & Teknostres & $\begin{array}{c}\text { Teknolojik } \\
\text { İş Yükü }\end{array}$ & $\begin{array}{c}\text { Teknolojik } \\
\text { Belirsizlik }\end{array}$ & $\begin{array}{c}\text { Teknolojik } \\
\text { Karmaşılık }\end{array}$ \\
\hline Çarpıklık &, 145 &, 274 &, 645 &,- 220 &, 333 \\
Basıklık &,- 570 &, 252 &,- 401 &,- 568 &,- 063 \\
\hline
\end{tabular}

\subsubsection{Değişkenler Arası İlişkiler Analizi}

Zaman baskısı ve teknostres ile alt boyutları arasındaki ilişkileri belirlemek amacıyla yapılan korelasyon analizi, değişkenlere ait aritmetik ortalama ve standart sapmalar Tablo 5'de sunulmuştur.

Tablo 5. Korelasyon Analizi 
R. Çoban - T. Aydoğdu 12/3 (2020) 2442-2460

\begin{tabular}{lccccccc}
\hline Değişkenler & Ort. & S.S. & $\mathbf{1}$ & $\mathbf{2}$ & $\mathbf{3}$ & $\mathbf{4}$ & $\mathbf{5}$ \\
\hline 1. Zaman Baskısı & 3,01 &, 81 & - & & & & \\
2. Teknostres & 2,62 &, 68 &, $349^{* *}$ & - & & & \\
3. Teknolojik İş Yükü & 2,42 & 1,02 &, $325^{* *}$ &, $849^{* *}$ & - & & \\
4. Teknolojik Belirsizlik & 3,05 &, 94 &, 065 &, $600^{* *}$ &, $220^{* *}$ & - & \\
5. Teknolojik Karmaşıklık & 2,44 &, 80 &, $370^{* *}$ &, $703^{* *}$ &, $493^{* *}$ &, 130 & - \\
\hline
\end{tabular}

** $\mathrm{p}<0,01 \mathrm{~N}: 177$

İslamoğlu ve Alnıaçık'a (2014: 347) göre korelasyon katsayısıyla ilgili şu değerlendirmeler yapılır: ,10-,30 arası zayıf; ,30-,50 arası orta; ,50-,80 arası güçlü ve ,80'den büyük ise çok güçlü korelasyon vardır. Tablo 5 incelendiğinde zaman baskısı ile teknostres $(, 349)$, teknolojik iş yükü $(, 325)$ ve teknolojik karmaşıklık $(, 370)$ arasında pozitif yönlü orta seviyede bir ilişki; teknolojik belirsizlik $(, 065)$ arasında ise bir ilişki olmadığ1 görülmüsşür. Bununla birlikte, teknostres ile alt boyutları arasında (teknolojik iş yükü: ,849; teknolojik belirsizlik: ,600; teknolojik karmaşıklık: ,703) güçlü ve çok güçlü ilişkilerin olduğu; teknolojik belirsizlik ile teknolojik karmaşıklık arasındaki ilişkinin $(, 130)$ ise zayıf olduğu görülmüştür. Değişkenlere ait aritmetik ortalamalara bakıldığında bakım teknisyenlerinin zaman baskısı (ort: 3,01) ve teknolojik belirsizlik (ort: 3,05) algılarının orta seviyede; teknostres (ort: 2,62), teknolojik iş yükü (ort: 2,42) ve teknolojik karmaşıklık (ort: 2,44) algılarının ise kısmen düşük olduğu görülmüştür.

\subsubsection{Zaman Baskısının Teknostrese Etkisi}

Zaman baskısının teknostrese etkisini ölçmek amacıyla yapılan basit doğrusal regresyon analizi Tablo 6'da sunulmuştur.

Tablo 6. Regresyon Analizi

\begin{tabular}{cccc}
\hline \multicolumn{4}{c}{ Regresyon Modeli Özeti } \\
\hline $\mathbf{R}$ & $\mathbf{R}^{2}$ & Düzeltilmiş $\mathbf{R}^{2}$ & Standart Hata \\
, 349 & 122 &, 117 &, 64 \\
Bağımlı Değişken: Teknostres & & ANOVA: $(\mathrm{F}(1,175): 24,331 ; \mathrm{p}:, 000<, 001) \mathrm{N}: 177$ \\
\hline
\end{tabular}

Tablo 6'da görülen regresyon modeli sonuçlarının ANOVA testine göre istatistiksel olarak anlamlı $[\mathrm{F}(1,175)$ : 24,331; p: ,000 < 0,001] olduğu görülmüştür. Analiz sonucu düzeltilmiş $\mathrm{R}^{2}$ değeri 0,11'dir. Bu sonuç; bakım teknisyenlerinin teknostres algısındaki yaklaşık \%11 oranındaki değişimin, teknisyenlerin hissettiği zaman baskısı tarafından açıklandığını göstermektedir. Başka bir ifadeyle, zaman baskısının teknostresi pozitif olarak etkilediği görülmüştür.

\subsubsection{Demografik Özelliklere Göre Karşılaştırma Analizleri}

Demografik özelliklere göre bakım teknisyenlerinin zaman baskısı ve teknostres algısının farklılık gösterip göstermediğini belirlemek amacıyla yapılan T-testi ve ANOVA testi sonuçları tablolar halinde sunulmuştur. Araştırmada kadın katılımcı olmadığından dolayı cinsiyete göre bir karşılaştırma yapılmamıştır.

Tablo 7. Medeni Duruma Göre Zaman Baskısı ve Teknostres Algısı

\begin{tabular}{cccccccccccc}
\hline Medeni & $\mathbf{N}$ & \multicolumn{4}{c}{ Zaman Baskısı } \\
\cline { 3 - 10 } & & Ort. & S.S. & $\mathbf{d f}$ & $\mathbf{t}$ & $\mathbf{P}$ & Ort. & S.S. & $\mathbf{d f}$ & $\mathbf{t}$ & $\mathbf{P}$ \\
Evli & 146 & 3,00 &, 82 & 201 &,- 340 &, 735 & 2,59 &, 67 & 175 & $-1,067$ &, 287 \\
Bekâr & 31 & 3,06 &, 75 & & & & 2,73 &, 70 & & & \\
\hline
\end{tabular}

* $\mathrm{P}<0,05$ ise anlamlı farklılık vardır.

Tablo 7' deki T-testi sonuçları incelendiğinde medeni duruma göre bakım teknisyenlerinin zaman baskısı (P: $, 735>, 050)$ ve teknostres (P: ,287>,050) algısının anlamlı bir farklılık göstermediği görülmüştür. 
R. Çoban - T. Aydoğdu 12/3 (2020) 2442-2460

Tablo 8. Yaş Gruplarına Göre Zaman Baskısı ve Teknostres Algısı

\begin{tabular}{cccccccccc}
\hline Yaş & $\mathbf{N}$ & \multicolumn{4}{c}{ Zaman Bask1S1 } & \multicolumn{5}{c}{ Teknostres } \\
\cline { 3 - 9 } Grubu & & Ort. & S.S. & $\mathbf{F}$ & $\mathbf{P}$ & Ort. & S.S. & $\mathbf{F}$ & $\mathbf{P}$ \\
$\mathbf{2 0 - 2 7}$ & 19 & 3,33 &, 79 & 1,823 &, 127 & 3,05 &, 72 & 2,433 &, 049 \\
$\mathbf{2 8 - 3 5}$ & 90 & 3,08 &, 89 & & & 2,58 &, 70 & & \\
$\mathbf{3 6 - 4 2}$ & 48 & 2,81 &, 68 & & & 2,57 &, 60 & \\
$\mathbf{4 3 - 4 9}$ & 18 & 2,88 &, 56 & & & 2,53 &, 58 & \\
$\mathbf{5 0 - 5 6}$ & 2 & 3,20 &, 41 & & & 2,19 &, 27 & \\
Toplam & 177 & 3,01 &, 80 & & & 2,62 &, 68 & \\
\hline
\end{tabular}

* $\mathrm{P}<0,05$ ise anlamlı farklılık vardır.

Tablo 8' deki ANOVA testi sonuçları incelendiğinde yaş gruplarına göre bakım teknisyenlerinin zaman baskısı algısında (P: ,127>,05) anlamlı bir farklılık yok iken; teknostres algisında (P: ,049<,05) anlamlı bir farklılık olduğu görülmüştür. Tukey testi sonuçlarına göre, 20-27 ve 28-35 yaş grubu teknisyenlerin teknostres algisı arasında anlamlı bir farklılık olduğu ve 20-27 yaş grubu teknisyenlerin (ort: 3,05) 28-35 yaş grubu teknisyenlerle $(2,58)$ karşılaştırıldığında daha fazla teknostres hissettiği görülmüştür.

Tablo 9. Çalışma Süresine Göre Zaman Baskısı ve Teknostres Algısı

\begin{tabular}{cccccccccc}
\hline Çalışma & $\mathbf{N}$ & \multicolumn{3}{c}{ Zaman Baskisi } & \multicolumn{5}{c}{ Teknostres } \\
\cline { 3 - 9 } Süresi & & Ort. & S.S. & $\mathbf{F}$ & $\mathbf{P}$ & Ort. & S.S. & $\mathbf{F}$ & $\mathbf{P}$ \\
3 Yıldan Az & 9 & 2,40 &, 48 & 4,888 &, 000 & 2,69 &, 49 & 1,253 &, 287 \\
$\mathbf{3 - 8}$ & 19 & 3,74 &, 66 & & & 2,97 &, 76 & & \\
$\mathbf{9 - 1 4}$ & 57 & 2,91 &, 83 & & & 2,55 &, 74 & \\
$\mathbf{1 5 - 2 0}$ & 54 & 3,04 &, 82 & & 2,57 &, 68 & \\
$\mathbf{2 0 - 2 5}$ & 26 & 2,94 &, 72 & & & 2,61 &, 54 & \\
$\mathbf{2 5 +}$ & 12 & 2,85 &, 52 & & & 2,55 &, 49 & \\
Toplam & 177 & 3,01 &, 80 & & & 2,62 &, 68 & \\
\hline
\end{tabular}

* $\mathrm{P}<0,05$ ise anlamlı farklılık vardır.

Tablo 9'daki ANOVA testi sonuçları incelendiğinde çalışma süresine göre teknisyenlerin teknostres algısında (P: ,287>,05) anlamlı bir farklılık yok iken; zaman baskısı algısında (P: ,000<,05) anlamlı bir farklılık olduğu görülmüştür. Tukey testi sonuçlarına göre 3-8 yıl çalışma süresine sahip teknisyenler ile 3 yıldan az, 9-14, 15$20,20-25$ ve 25 yıl üzeri çalışma süresine sahip teknisyenlerin zaman baskısı algısı arasında anlamlı bir farklılık olduğu; 3-8 yıl çalışma süresine sahip teknisyenlerin (ort: 3,74), 9-14 (ort: 2,40), 15-20 (ort: 2,91), 20-25 (ort: 3,04) ve 25 yıl üzeri (ort: 2,85) çalışma süresine sahip teknisyenler ile karşılaştırıldığında daha fazla zaman baskısı hissettiği görülmüştür.

Tablo 10. Eğitim Durumuna Göre Zaman Baskısı ve Teknostres Alg1sı 


\begin{tabular}{cccccccccc}
\hline Eğitim & $\mathbf{N}$ & \multicolumn{4}{c}{ Zaman Bask1sı } & \multicolumn{5}{c}{ Teknostres } \\
\cline { 3 - 9 } Durumu & & Ort. & S.S. & $\mathbf{F}$ & $\mathbf{P}$ & Ort. & S.S. & $\mathbf{F}$ & $\mathbf{P}$ \\
Lise & 2 & 3,08 & 1,76 & 3,155 &, 016 & 2,23 &, 11 & 4,565 &, 002 \\
Yüksekokul & 39 & 3,31 &, 83 & & & 2,94 &, 80 & & \\
Lisans & 125 & 2,90 &, 76 & & & 2,49 &, 62 & \\
Yük. Lisans & 9 & 3,47 &, 74 & & & 2,95 &, 33 & \\
Doktora & 2 & 2,33 &, 35 & & & 3,07 &, 65 & \\
Toplam & 177 & 3,01 &, 80 & & & 2,62 &, 68 & \\
\hline
\end{tabular}

* $\mathrm{P}<0,05$ ise anlamlı farklılık vardır.

Tablo 10'daki ANOVA testi sonuçları incelendiğinde eğitim durumuna göre teknisyenlerin hem zaman baskısı (P: ,016<,05) hem de teknostres algısında (P: ,002<,05) anlamlı bir farklılık olduğu görülmüştür. Tukey testi sonuçlarına göre, yüksekokul ve lisans mezunu teknisyenlerin zaman baskısı algısında anlamlı bir farklılık olduğu ve yüksekokul mezunu teknisyenlerin (ort: 3,31) lisans mezunu teknisyenlerle (ort: 2,90 ) karşılaştırıldığında daha fazla zaman baskısı hissettiği; bununla birlikte yüksekokul ve lisans mezunu teknisyenlerin teknostres algısı arasında anlamlı bir farklılık olduğu ve yüksekokul mezunu teknisyenlerin (ort: 2,94) lisans mezunu teknisyenlerle (ort: 2,49) karşılaştırıldığında daha fazla teknostres hissettiği görülmüştür.

Tablo 11. Görev Ünvanına Göre Zaman Baskısı ve Teknostres Alg1sı

\begin{tabular}{cccccccccccc}
\hline Görev & $\mathbf{N}$ & \multicolumn{4}{c}{ Zaman Bask1s1 } & \multicolumn{6}{c}{ Teknostres } \\
\cline { 3 - 10 } Ünvan1 & & Ort. & S.S. & Df & $\mathbf{t}$ & $\mathbf{P}$ & Ort. & S.S. & df & $\mathbf{t}$ & $\mathbf{P}$ \\
T. Kontrol & 8 & 2,67 &, 62 & 175 & $-1,219$ &, 224 & 2,27 &, 71 & 175 & $-1,461$ &, 146 \\
Teknisyen & 169 & 3,03 &, 81 & & & & 2,63 &, 67 & & & \\
\hline
\end{tabular}

* $\mathrm{P}<0,05$ ise anlamlı farklılık vardır.

Tablo 11'deki T-testi sonuçları incelendiğinde görev ünvanına göre bakım teknisyenlerinin zaman baskısı (P: ,224>,05) ve teknostres (P: ,146>,05) algısının anlamlı bir farklılık göstermediği görülmüştür.

\section{Sonuç ve Tartışma}

Zaman kavramı, günlük hayatta bireylerin hem sosyal faaliyetleri hem de işlerini yaparken dikkate alması gereken önemli bir olgudur. Çünkü zaman; anında kullanılan, yedeklenemeyen, çoğaltılamayan, değerli ve kıt bir kaynaktır. Bu nedenle örgütsel yaşamda çalışanlar tarafından zamanın verimli kullanılması ve iyi yönetilmesi gerekir. Bir işi tamamlamak için gereken zaman azaldığında, bireyler zaman baskısı hisseder. Zakay'a (1993: 60) göre; zaman baskısı altındaki bireyler, bilişsel kaynaklarını yeteri kadar kullanamaz ve karmaşık görevlerdeki bireysel performans negatif olarak etkilenir. Bundan dolayı, zaman baskısı önemli bir stres kaynağıdır. Günümüzün modern dünyasında teknolojik gelişmelere bağlı olarak, tüm işletmeler etkin ve verimli bir örgütsel performans için teknolojik araçları kullanmaya önem vermektedir. Teknoloji, örgütsel ve bireysel performansın artışında önemli katkılar sağlamakla birlikte, bazı yönleriyle de çalışanları strese sokmaktadır. Tarafdar vd.'ne (2011: 304) göre; teknoloji kullanımı nedeniyle artan iş yükü, sürekli yapılması gereken güncellemeler, teknik sorunlar, teknolojik karmaşıklık ve belirsizlik, çalışanların teknostres yaşamasına neden olmaktadır. Literatür taraması sırasında havacılık sektöründe uçak bakım faaliyetlerinin yerine getirilmesinde, zaman baskısı ve teknostres kavramlarının insan faktörü kaynaklı hatalara sebep olan birbiriyle ilişkili iki önemli faktör olduğu görülmüştür. Bu kapsamda bu araştırmada, havacilık sektöründe zaman baskısının teknostrese etkisi ve demografik özelliklere göre bakım teknisyenlerinin zaman baskısı ve teknostres algısının farklılık gösterip göstermediği ortaya konulmaya çalışılmıştır.

Araştırmanın hipotezlerini test etmek amacıyla yapılan korelasyon analizi sonucunda, zaman baskısı ile teknostres, teknolojik iş yükü ve teknolojik karmaşıklık arasında pozitif yönlü orta seviyede bir ilişki olduğu görülürken; zaman baskısı ile teknolojik belirsizlik arasında ise bir ilişki olmadığı görülmüştür. Bu kapsamda, 
" $\mathrm{H}_{1}$ : Bakım teknisyenlerinin algıladı̆̆̆ zaman baskısı ile teknostres arasında anlamlı pozitif bir ilişki vardır." hipotezi kabul edilmiştir. Değişkenlere ait aritmetik ortalamalara bakıldığında; bakım teknisyenlerinin hissettiği zaman baskısının (ort: 3,01) teknostres (ort: 2,62)'den daha fazla olduğu görülmüştür. Cheng (2018: 123), ticari kaygılar nedeniyle uçak bakım sektöründe görülen zaman baskısı ve sektördeki hızlı teknolojik değişimin stres kaynağı olduğunu; Ariely ve Zakay (2001:187), zaman baskısı altında karar alan bireylerin bilişsel hatalar yaptığını; Hendy vd. (2001) ise, zaman baskısının çalışanın iş yükünü arttırdığını ve temel bir stres kaynağı olduğunu ifade etmiştir. Bu nedenle $\mathrm{H}_{1}{ }^{\prime} \mathrm{e}$ ait araştırma bulgularının bahsedilen araştırma bulguları ile uyum içinde olduğunu söylemek mümkündür.

Zaman baskısının teknostrese etkisini ölçmek amacıyla yapılan basit doğrusal regresyon analizi sonucunda, regresyon modelinin anlamlı olduğu; zaman baskısının teknostresi pozitif olarak etkilediği ve bakım teknisyenlerinin teknostres algısındaki yaklaşık \%11 (Düzeltilmiş $R^{2}: 0,11$ ) oranındaki değişimin teknisyenlerin algıladığı zaman baskısı tarafından belirlendiği görülmüştür. Bu kapsamda, " $\mathrm{H}_{2}$ : Zaman baskısı, bakım teknisyenlerinin algıladığı teknostresi pozitif olarak etkiler." hipotezi kabul edilmiştir. Moray (1980), zaman baskısının çalışanın sübjektif iş yükünü arttırdığını; Tarafdar vd. (2007: 309), teknoloji ile yoğun çalışanların aynı anda çoklu görevlere ve teknolojik iş yüküne maruz kaldığı için daha fazla zamana ihtiyaç duyduğunu, böyle durumlarda zaman sınırlı ise çalışanın dikkatinin dağıldığını, aşırı iş yükü ve tükenmişlikle birlikte teknostresin ortaya çıktığını; Bachiller (2001), artan zaman baskısının teknostres, fiziksel ve psikolojik sorunlara yol açtığını; Çoban (2019: 52) ise, zaman baskısının uçak bakım sektöründe iş yükünün artmasına, kalite standartlarının düşmesine, yorgunluğa, insan faktörü hatalara ve strese neden olduğunu ifade etmiştir. Bu nedenle $\mathrm{H}_{2}$ 'ye ait araştırma bulgularının bahsedilen araştırma bulguları ile uyum gösterdiği söylenebilir.

Demografik özelliklere göre yapılan karşılaştırma analizleri sonucunda, medeni durum ve görev ünvanına göre bakım teknisyenlerinin zaman baskısı ve teknostres algısında anlamlı bir farklılık olmadığı görülmüştür. Yaş gruplarına göre yapılan karşılaştırma analizlerine bakıldığında, teknisyenlerin zaman baskısı algısında anlamlı bir farklılık yok iken; teknostres algısında anlamlı bir farklılık olduğu; 20-27 yaş grubunun 28-35 yaş grubuna göre daha fazla teknostres hissettiği görülmüştür. 20-27 yaş grubu teknisyenler, çalışma hayatının başında olan, deneyimsiz ve genç çalışanlardır. Genç çalışanların teknolojik değişimlere daha kolay uyum sağlayabileceği düşünülebilir. Ancak, genç çalışanların iş deneyimlerinin az olması, örgütsel stres kaynakları ile başa çıkmalarını olumsuz etkileyebilir. Tarafdar vd.'ne (2011: 119-120) göre, daha fazla çalışma deneyimine sahip yaşlı çalışanların genellikle stresle mücadele yeteneği yüksektir. Çalışma süresine göre yapılan karşılaştırma analizlerine bakıldığında, teknisyenlerin teknostres algısında anlamlı bir farklılık yok iken; zaman baskısı algısında anlamlı bir farklılık olduğu; 3-8 yıl çalışma süresine sahip teknisyenlerin diğer çalışma süresine sahip teknisyenlerle karşılaştırıldığında daha fazla zaman baskısı hissettiği görülmüştür. 3-8 yıl çalışma süresine sahip teknisyenler, genellikle uçak bakım faaliyetleri ile ilgili örgütsel kurallara adapte olmaya ve deneyim kazanmaya çalışan genç teknisyenlerdir. Bununla birlikte genç ve deneyimsiz olmaları nedeniyle yönetsel işlerden ziyade daha çok bedenen çalışarak bakım işlemlerini belirli zaman sınırları içinde yapmaya çalışırlar. Bu nedenle, söz konusu gruptaki teknisyenlerin iş yükü artabileceğinden ve deneyimleri de az olduğundan zaman baskısı yaşayabilir.

Eğitim durumuna göre yapılan karşılaştırma analizlerine bakıldığında, teknisyenlerin zaman baskısı ve teknostres algısında anlamlı bir farklılık olduğu; yüksekokul mezunlarının lisans mezunu teknisyenlerle karşılaştırıldığında daha fazla hem zaman baskısı hem de teknostres hissettiği görülmüştür. Tarafdar vd.'ne (2011: 119-120) göre, eğitim seviyesi arttıkça bireylerin teknoloji kullanımı ve teknolojiye uyumu artacağından teknostres seviyesi düşebilir. Aynı şekilde, eğitim seviyesi arttıkça bireylerin zaman baskısı ile mücadele etme konusunda deneyim kazanabileceğini ve kısıtlı zamanlarını daha iyi yönetebileceğini söylemek mümkündür. Bu kapsamda, " $H_{3}$ : Demografik özelliklere göre bakım teknisyenlerinin zaman baskısı algısı farklıdır." ve " $H_{4}$ : Demografik özelliklere göre bakım teknisyenlerinin teknostres algısı farklıdır." hipotezlerinin kabul edildiği görülmüştür. $\mathrm{H}_{3}$ 'e ait araştırma bulgularının Gunthorpe ve Lyons'un (2004: 208) araştırma sonucuyla uyumlu; Earles vd.'nin (2004: 285) araştırma sonucuyla uyumsuz olduğu; $\mathrm{H}_{4}$ 'e ait araştırma bulgularının Tarafdar vd. (2011: 119-120) ile Türen vd.'nin (2015: 13) araştırma sonuçlarıyla uyumlu olduğu görülmüştür.

Havacılık sektöründe uçak bakım teknisyenleri üzerine yapılan bu araştırma sonucunda, zaman baskısının teknostresi pozitif olarak etkilediği ve demografik özelliklere göre bakım teknisyenlerinin zaman baskısı ve teknostres algısının farklılaştığı görülmüştür. Bu kapsamda hava yolu işletmeleri ve yöneticilerine bazı önerilerde bulunulabilir. Uçak bakım sektöründe zaman baskısı ve teknostresin bakım teknisyenlerinin 
performansını etkileyen ve birbiriyle ilişkili iki kavram olduğu unutulmamalıdır. Zaman baskısı ile mücadele edebilmek için işyerindeki teknisyen sayısı, gerekli araç gereç, teknik doküman gibi kaynakların niteliği ve niceliği arttırılmalı; günlük, haftalık ve aylık iş yükü planları yeniden düzenlenmeli; zaman kaybına neden olan örgütsel faktörler üzerinde iyileştirmeler yapılmalı ve teknisyenlere zaman yönetimi eğitimleri verilmelidir. Bununla birlikte, teknisyenlerin teknostres ile başa çıkabilmesi için teknolojik iş yükü teknisyenlere eşit dağıtılmalı; yeni teknolojilere uyum sağlamak amacıyla temel ve tazeleme eğitimleri verilmeli; teknik sorunlar ve güncellemeler zamanında yapılmali; teknostresin fiziksel ve psikolojik negatif etkilerini önlemek için çalışma süreleri yeniden düzenlenmeli ve sosyal faaliyetlere önem verilmelidir.

Araştırmanın sadece Malatya ilinde kamu sektöründe çalışan uçak ve helikopter bakım teknisyenleri üzerinde uygulanması ve kadın katılımcı olmaması nedeniyle kısıtları bulunmaktadır. Bununla birlikte, araştırma sonucu elde edilen bulguların havacılık, uçak bakım, uçuş emniyeti, havacılıkta insan faktörü gibi alanlardaki sınırlı literatüre özgün katkı sağlayacağı ve gelecekte yapılacak araştırmalara ışık tutacağı düşünülmektedir. Bu kapsamda, bakım teknisyenleri üzerine çalışılan zaman baskısı ve teknostres kavramları pilot, kabin memuru, hava trafik ve yer personeli gibi diğer havacılık sektörü çalışanları üzerinde de çalışılabilir. Ayrıca gelecekte yapılacak çalışmalarda zaman baskısı ile iletişim tarzı, karar alma süreci, performans ilişkisi; teknostres ile iş tatmini, tükenmişlik ve performans ilişkisi araştırılabilir.

\section{KAYNAKÇA}

Ahmad, U.N.U., Amin, S.M. and İsmail, W.K.W. (2009). The impact of technostress on organisational commitment among malaysian academic librarians, Singapore Journal of Library \& Information Management, 38, 03-123.

Akınoğlu, H.F. (1993). Teknostres, Türk Kütüphaneciliği Dergisi, 7 (3), 159-173.

Alam, M.A. (2016). Tekno-stres and productivity: survey evidence from aviation industry, Journal of Air Transport Management, 50, 62-70.

Ariely, D. and Zakay, D. (2001). A timely account of the role of duration in decision making, Acta Psychologica, $108,187-207$.

Bachiller, R.T. (2001). Technostress Among Library Staff and Patrons of The U.P. Diliman Libraries, Unpublished Undergraduate Thesis, University of the Philippines, Diliman.

Bozacı, İ. (2019). Bireysel zaman baskısının satın alma sonrası pişmanlığa etkisinde alışverişte zaman baskısının aracı rolü üzerine bir araştırma, Uluslararası Toplum Araştırmaları Dergisi, 10 (17), 653-676.

Brillhart, P.E. (2004). Technostress in the workplace: managing stress in the electronic workplace Journal of American Academy of Business, 5 (1/2), 302-307.

Brod, C. (1984). Technostress: The Human Cost of the Computer Revolution, Reading: Addison-Wesley.

Cangur, Ş. and Ercan, İ. (2015). Comparison of model fit indices used in structural equation modeling under multivariate normality, Journal of Modern Applied Statistical Methods, 14 (1), 52-167.

Cella, M., Dymond, S., Cooper, A. and Turnbull, O. (2007). Effects of decision-phase time constraints on emotion-based learning in the iowa gambling task, Brain and Cognition, 64 (2), 164-169.

Chen, L. (2015). Validating the technostress instrument using a sample of chinese knowledge workers, Journal of International Technology and Information Management, 24 (1), 65-82.

Cheng, R. (2018). Human factor analysis about human error on aviation maintenance, 4th International Conference on Social Science and Higher Education, 181, 120-124.

Çelik, M. ve Özdemir, A. (2016). Çalışanların tekno-stres seviyelerinin örgütsel sinizm üzerine etkisi: bankacılık sektöründe bir araştırma, IV. Örgütsel Davranış Kongresi, Adana, Türkiye, 4-5 Kasım 2016, 256-263.

Çoban, R. (2017). Bakım kaynak yönetimi: uçak bakımda insan faktörü üzerine bir araştırma, Havacıllk Emniyeti Yönetim Sistemi Sempozyumu, Ankara, Türkiye, 12-13 Nisan 2017, 88-113. 
Çoban, R. (2019). Uçak bakım sektöründe iş yükü ve zaman baskısı üzerine bir örnek olay araştırması, Journal of Aviation, 3 (1), 45-60.

Dhar, R., Nowlis, S.M. and Sherman, S.J. (2000). Trying hard or hardly trying: an analysis of context effects in choice, Journal of Consumer Psychology, 9 (4), 189-200.

Dreu, C.K.D. (2003). Time pressure and closing of the mind in negotiation, Organizational Behavior and Human Decision Processes, 91 (2), 280-295.

Earles, J.L., Kersten, A.W., Mas, B.B. and Miccio, D.M. (2004). Aging and memory for self-performed tasks: effects of task difficulty and time pressure, Journal of Gerontology: Psychological Sciences, 59B (6), 285-293.

Ennis, L.A. (2005). The evolution of technostress, Computers in Libraries, 25 (8), 10-12.

Eren, E. (2016). Yönetim ve Organizasyon, İstanbul, Beta Yayınları.

Gunthorpe, W. and Lyons, K. (2004). A predictive model of chronic time pressure in the australian population: implications for leisure research, Leisure Sciences, 26 (2), 201-213.

Güran, R. ve Güler, B.K. (2019). Termik santral çalışanlarında iş yükü ve zaman baskısının tükenmişlik üzerindeki etkisi: iş-aile çatışmasını yönetme öz-yeterliğinin aracılık etkisi, İktisat Araştırmaları Dergisi, 3 (2), 153-176.

Gürbüz, S. (2019). AMOS ile Yapısal Eşitlik Modellemesi, Birinci Baskı, Ankara, Seçkin Yayıncılık.

Gürbüz, S. ve Şahin, F. (2017). Sosyal Bilimlerde Araştırma Yöntemleri Felsefe-Yöntem-Analiz, 4. Baskı, Ankara, Seçkin Yayıncılık.

Hammond K.R. (2000). Judgment Under Stress, New York, Oxford University Press.

Hendy, K.C., Farrell P.S.E. and East, K.P. (2001). An Information-Processing Model of Operator Stress And Performance, In P.A. Hancock, \& P.A. Desmond (Eds.), Stress, Workload and Fatigue. Mahwah, NJ: L. Erlbaum.

Huber, O and Kunz, U. (2007). Time pressure in risky decision-making: effect on risk defusing, Psychology Science, 49 (4), 415-426.

Hudiburg, R.A. (1996). Assessing and Managing Technostress, https://www.una.edu/psychology, (Erişim tarihi: 10 Mayıs 2019).

Isenberg, D.J. (1981). Some effects of time-pressure on vertical structure and decision making accuracy in small groups, Organizational Behavior and Human Performance, 27 (1), 119-134.

İslamoğlu, H. ve Alnıaçık, Ü. (2014). Sosyal Bilimlerde Araştırma Yöntemleri, (4. Baskı), İstanbul, Beta Yayıncılık.

Karakoç, N. (1990). İşletmelerde etkenliği belirleyen bir kaynak: yönetsel zaman, Verimlilik Dergisi, 2, 33-44.

Khedhaouria, A., Montani, F. and Thurik, R. (2017). Time pressure and team member creativity within R\&D projects: the role of learning orientation and knowledge sourcing, International Journal of Project Management, 35 (6), 942-954.

Latorella, K.A. and Prabhu, P.V. (2000). A review of human error in aviation maintenance and inspection, International Journal of Industrial Ergonomics, 26, 133-161.

Longinus, O., Odigbo, B. and Onwumere, J.U.J. (2013). Effect of techno-stress on the performance of accountants and other managers in nigerian banking and brewery industries, European Journal of Business and Management, 5 (14), 100-108.

MacCallum, R.C., Browne, M.W. and Sugawara, H.M. (1996). Power analysis and determination of sample size for covariance structure modeling, Psychological Methods, 1 (2), 130-149.

Mahboob, A. and Khan, T. (2016). Technostress and its management techniques: a literature review, Journal of Human Resource Management, 4 (3), 28-35.

Malik, S.A. (2015). Time pressure and challenge appraisal as predictors of job satisfaction: empirical evidence from pakistani universities, SAGE Open, 5 (2), 1-9. 
R. Çoban - T. Aydoğdu 12/3 (2020) 2442-2460

Maruping, L.M., Venkatesh, V., Thatcher, S.M.B. and Patel, P.C. (2015). Folding under pressure or rising to the occasion? perceived time pressure and the moderating role of team temporal leadership, Academy of Management Journal, 58 (5), 1313-1333.

Maulana, R.M.S. and Rufaidah, P. (2014). Co-creation of small-medium enterprises, Procedia-Social and Behavioral Sciences, 115, 198-206.

Meral, B.F. and Takunyac1, M. (2016). Turkish adaptation, validity and reliability studies of teaching mathematics in inclusive settings survey, Sakarya University Journal of Education, 6 (2), 97-107.

Meydan, C.H. ve Şeşen, H. (2015). Yapısal Eşitlik Modellemesi AMOS Uygulamaları, 2. Baskı, Ankara, Detay Yayıncilik.

Moore, D.A. and Tenney, E.R. (2012). Time pressure, performance, and productivity, Research on Managing Groups and Teams, 15, 305-326.

Moray, N. (1980). Subjective measurement of mental workload arlington, Virginia: Office of Naval Research, Contract N00014-77-C0256.

Nawe, J. (1995). Work-related stress among the library and information workforce. Library Review, 44 (6), 3037.

Nimrod, G. (2018). Technostress: measuring a new threat to well-being in later life, Aging \& Mental Health, 22 (8), 1080-1087.

Ordonez, L.D. and Benson, L. (1997). Decisions under time pressure: how time constraint affects risky decision making, Organizational Behavior and Human Decision Processes, 71 (2), 121-140.

Ordonez, L.D., Benson L. and Pittarello, A. (2015). Time-Pressure Perception and Decision Making, The Wiley Blackwell Handbook of Judgment and Decision Making, First Edition, John Wiley \& Sons Ltd.

Owusu-Ansah, S., Quarshie Azasoo, J. and Nyarko Adu, I. (2016). Understanding the effects of techno-stress on the performance of banking staff, Int. Journal of Business Continuity and Risk Management, 6 (3), 222237.

Padil, H., Said, M.N. and Azizan, A. (2018). The contributions of human factors on human error in malaysia aviation maintenance industries, International Conference on Aerospace and Mechanical Engineering (AeroMech17), 370, 1-6.

Paola D.M. and Gioia, F. (2014). Who performs better under time pressure? results from a field experiment, IZA Discussion Paper, 8708, 1-21.

Paola D.M. and Gioia, F. (2016). Who performs better under time pressure? results from a field experiment. Journal of Economic Psychology, 53, 37-53.

Pietsch, C.P.R. and Messier, W.F. (2017). The effects of time pressure on belief revision in accounting: a review of relevant literature within a pressure-arousal-effort-performance framework, Behavioral Research In Accounting, 29 (2), 51-71.

Ragu-Nathan, T.S., Tarafdar, M. and Ragu-Nathan, B.S. (2008). The consequences of technostress for end users in organizations: conceptual development and empirical validation, Information Systems Research, 19 (4), 417-433.

Reason, J. and Maddox, M.E. (1995). Human error. In: Human Factors Guide for Aviation Maintenance. U.S. Department of Transportation, Washington, DC (Chapter 14).

Salanova, M., Gumbau, S.L. and Cifre, E. (2013). The dark side of technologies: technostress among users of information and communication technologies, International Journal of Psychology, 48 (3), $422-436$.

Sanderlin, T.K. (2004). Managing technostress in the organizational environment: symptoms and solutions, Journal of Psychology and Mental Health, 7 (1), 1-6. 
R. Çoban - T. Aydoğdu 12/3 (2020) 2442-2460

Saptari, A., Leau, J.X. and Mohamad, N.A. (2015). The effect of time pressure, working position, component bin position and gender on human error in manual assembly line, International Conference on Industrial Engineering and Operations Management, Dubai, United Arab Emirates (UAE), 3-5 March 2015, 1-6.

Sarıipek, D.B. (2016). Zaman baskısı altında çalışma ve boş zaman algısı, Yönetim ve Ekonomi Araştırmaları Dergisi, 14 (4), 112-127.

Schreuder, E.J.A. and Mioch, T. (2011). The effect of time pressure and task completion on the occurrence of cognitive lockup, CEUR Proceedings 4th Workshop HCP Human Centered Processes, February 10-11, 2011, 63-74.

Shurchkov, O. (2012). Under pressure: gender differences in output quality and quantity under competition and time constraints, Journal of the European Economic Association, 10, 1189-1213.

Smith, H.W. (1998). Hayat ve Zamanı Yönetmenin 10 Doğal Yasası, (Çev. Adalet Çelbiş), İstanbul, Sistem Yayıncilik.

Şahin, Y. and Çoklar, A.N. (2009). Social networking users' views on technology and the determination of technostress levels, Procedia Social and Behavioral Sciences, 1, 1437-1442.

Tabachnick, B.G. and Fidell, L.S., (2013). Using Multivariate Statistics, Boston, Pearson.

Tacy, J.W. (2015). Technostress Effects on Technology Acceptance by Nurse Faculty, Doctorate Dissertation, The University of Texas at Tyler.

Tarafdar, M., Tu, Q. and Nathan, T.R. (2011). Impact of technostress on end-user satisfaction and performance, Journal of Management Information Systems, 27 (3), 303-334.

Tarafdar, M., Tu, Q. and Ragu-Nathan, R.S. (2007). The impact of technostress on role stress and productivity, Journal of Management Information Systems, 24 (1), 301-328.

Tarafdar, M., Tu, Q., Ragu-Nathan, T.S. and Ragu-Nathan, B.S. (2011). Crossing to the dark side: examining creators, outcomes, and inhibitors of technostress, Communications of the ACM, 54 (9), 113-120.

Taylor, J.C. (2000). The evolution and efectiveness of maintenance resource management (MRM), International Journal of Industrial Ergonomics, 26, 201-215.

Thayer, R.E. (1989). The Biopsychology of Mood and Arousal, New York, NY: Oxford University Press.

Torlak, Ö., Doğan, V. ve Özkara, B.Y. (2013). Üniversite öğrencilerinin yaşamlarında algıladıkları zaman baskısının plansız satın alma eğilimleri üzerindeki etkisi, Pazarlama ve Pazarlama Araştırmaları Dergisi, $12,1-20$.

Tu, Q., Wang, K. and Shu, Q. (2005). Computer-related technostress in China, Communications of the ACM, 48 (4), 77-81.

Türen, U., Erdem, H. ve Kalkın, G. (2015). İş yerinde tekno-stres ölçeği: havacılık ve bankacılık sektöründe bir araştırma, Çalışma İlişkileri Dergisi, 6 (1), ss. 1-19.

Virovac, D., Domitrović, A. and Bazijanac, E. (2017). The influence of human factor in aircraft maintenance, Promet Traffic\&Transportation, 29 (3), 257-266.

Yazgan, E. and Kavsaoğlu, M.Ş. (2017). Evaluation of stress affecting aircraft maintenance technician's performance, Int'l Journal of Computing, Communications \& Instrumentation Engg. (IJCCIE), 4 (1), 96-101.

Yener, S. (2018). Teknostresin iş performansı üzerindeki etkisi: tükenmişliğin aracı rolü, Afyon Kocatepe Üniversitesi Sosyal Bilimler Dergisi, 20 (2), 85-101.

Zakay, D. (1993). Time Pressure and Stress in Human Judgment and Decision Making, Edited by Ola Svenson and A. John Maule, New York, Plenum Press. 